See discussions, stats, and author profiles for this publication at: https://www.researchgate.net/publication/259176833

\title{
The relationship between dividend payout and corporate governance along
} the corporate life-cycle

Article in International Journal of Corporate Governance · January 2013

DOI: $10.1504 / \mathrm{IJCG} .2013 .055175$

CITATION

1

1 author:

Thomas O'Connor

National University of Ireland, Maynooth

35 PUBLICATIONS 113 CITATIONS

SEE PROFILE

Some of the authors of this publication are also working on these related projects:

Dividend Policy View project 


\title{
The relationship between dividend payout and corporate governance along the corporate life-cycle
}

\author{
Thomas O'Connor \\ Department of Economics, Finance and Accounting, \\ National University of Ireland Maynooth, \\ Maynooth, Co. Kildare, Ireland \\ E-mail: Thomas.g.oconnor@nuim.ie
}

\begin{abstract}
This study explores the relationship between the quality of corporate governance and corporate dividend payout at different stages of the corporate life-cycle. In a sample of 220 firms from 21 emerging market countries, I show that the outcome model of dividends, which predicts that dividend payout increases in the strength of shareholder rights, prevails all along the corporate life-cycle. In a final series of tests, I show that this relationship holds only in instances where corporate governance and creditor rights are strong. Hence, the agency cost of equity and debt version of the outcome model of dividends holds at all stages of the corporate life-cycle. Finally, I find no evidence in support of the equity-only version of the substitution model of dividends.
\end{abstract}

Keywords: corporate governance; agency models of dividends; corporate life-cycle; creditor rights; emerging markets.

Reference to this paper should be made as follows: O'Connor, T. (2013) 'The relationship between dividend payout and corporate governance along the corporate life-cycle', Int. J. Corporate Governance, Vol. 4, No. 1, pp. $20-50$.

Biographical notes: Thomas O'Connor lectures in Finance at the Department of Economics, Finance and Accounting, NUI Maynooth, Ireland. His research interests are corporate finance, dividend policy, capital structure, international cross-listings, stock market liberalisations, and corporate governance.

\section{Introduction}

La Porta et al. (2000) present two agency cost models of dividends. The first model, what they term the outcome model, suggests that dividends are an outcome of effective governance, where governance can be either country governance i.e., legal rules or corporate governance, or their interaction (see Mitton, 2004; Bartram et al., 2012). Given the agency costs of free cash flow, shareholders prefer dividends to retained earnings since dividends reduce the pool of funds which can be consumed privately by controlling insiders/managers (see Jensen, 1986; Easterbrook, 1984). Presumably, while all shareholders have a preference for dividends given free cash flow, the outcome model suggests that it is the shareholders with the greatest legal rights (and/or belonging to better-governed firms) which can extract the largest dividends from firms. Hence, the theoretical prediction of the outcome model is that dividend payout increases in 
shareholder rights and free cash flow. However, when better-governed firms are young, growing fast, but still unprofitable (and thus presumably with negative free cash flow), recent work suggests that their shareholders do not demand larger dividends (La Porta et al., 2000; Mitton, 2004; Chae et al., 2009; Bartram et al., 2012). In effect, they substitute lower current dividends for expected higher future dividends. In stark contrast, the shareholders of young, yet poorly-governed firms do not agree to lower current dividends, and seek to extract as much as they can from firms in the form of a dividend. The logical conclusion from this line of reasoning, which is implicit in the assumptions underlying the agency models of dividends, is that the outcome model is more likely to prevail when firms are 'mature' (i.e., when they are characterised as having diminished investment opportunities, experience slower growth, are profitable, and as a result have positive free cash flow), but not necessarily so when firms are 'immature'.

The second model, referred to as the substitution model suggests that there exists a negative relationship between the strength of shareholder rights (and/or corporate governance) and corporate dividend payout. The underlying cause for this negative relationship relies on the notion that dividends paid can serve a bonding role for poorly-governed firms. The management of poorly-governed firms substitute higher (current and future) dividends for poor governance. They do so because higher dividends serve to establish a reputation for equitable treatment of current (and prospective shareholders), which in turn should allow these firms to access external capital at a much lower cost than they would have otherwise (Chen et al., 2009). In contrast, 'immature' better-governed firms, whom are much less likely to be financially constrained, but are growing fast, pay lower dividends, which is acceptable to their shareholders (Mitton, 2004; Chae et al., 2009). Consequently, this line of reasoning suggests that the substitution model of dividends is much more likely to manifest when firms are 'immature'.

In this paper, I examine the relationship between the strength of shareholder rights and the extent of corporate dividend payout along the corporate life-cycle. To do so, I exploit cross-sectional differences in corporate maturity, and test the outcome and substitution models of dividends for 'mature' and 'immature' firms. This approach contrasts notably with almost all other studies, since these studies test both agency models of dividends (or total payout), either in a single-year or in a panel setting, using a samples of firms at very different stages of their life-cycles. One of the shortcomings with this approach is that these tests assume that at any point in time, the agency models are mutually-exclusive, and as such, either the outcome or substitution model will prevail, but not both. However, since the outcome and substitution models are likely to manifest at different stages of the corporate life-cycle, tests which examine these models along the corporate life-cycle open up the possibility that both models can prevail for the same sample of firms, in the same time period (or periods), once we explore the relationship between governance and dividend payout for 'mature' and 'immature' firms separately. In this paper, I explore this possibility.

To perform these tests, I collect a sample of 220 firms from 21 emerging market countries. Like Mitton (2004), I test the agency models of dividends using shareholder rights measured at the corporate level (i.e., corporate governance), and when I include 'mature' and 'immature' firms together, I, like him find evidence in support of the outcome model. When I treat these same firms separately, I find no evidence to suggest that the equity-only version of the substitution model prevails when firms are 'immature'. 
In contrast, the outcome model manifests all along the corporate life-cycle i.e., for 'immature' and 'mature' firms. In a final set of tests, I find that the outcome model only prevails in instances of strong shareholder and creditor rights. Where creditor rights are weak, even given strong shareholder rights, dividend payouts tend to be much lower. Hence, the original agency cost of equity (i.e., the costs associated with the conflict between management/controlling insider and shareholders/outsiders) version of the outcome model of dividends, inclusive of the agency costs of debt equity (i.e., the costs associated with the conflict between the providers of capital to the firm, namely shareholders and creditors), which predicts that dividends are an outcome of strong shareholder and creditor rights, holds.

Thus, in summary, this paper serves to further our understanding of the agency models of dividends in a number of ways. First, I show that in an emerging market setting, the outcome model of dividends prevails at all stages of the corporate life-cycle for a sample of emerging market firms. Second, I show that this same relationship is contingent on strong shareholder and creditor rights. While this finding is not new, my findings here in this paper do serve to confirm the recent work of Brockman and Unlu (2009), Shao et al. (2009), Byrne and O'Connor (2012), who all highlight the profound influence that creditors exert over corporate dividend policy. What is new is that I show that this influence is exerted over the entire corporate life-cycle. Finally, I find no evidence in support of the substitution model of dividends. This finding suggests that even in countries where bonding devices are few (see Benos and Weisbach, 2004); poorly-governed firms do not appear to utilise dividends in a bonding role. Presumably, these firms use alternative bonding mechanisms (e.g., international cross-listings; development of strategic alliances).

The paper proceeds as follows. In the next section, I present a brief literature review and develop two hypotheses. From here, I describe the data and present the empirical findings. I end with some concluding remarks.

\section{Literature review and hypothesis development}

In this paper I test two agency models of dividends, namely the outcome and substitution models of La Porta et al. (2000) at different stages of the corporate life-cycle. The corporate life-cycle model of dividends (see for example Grullon et al. (2002), DeAngelo et al. (2006), Bulan et al. (2007), Denis and Osobov (2008)) suggests that the likelihood of paying a dividend in the first instance, and the dividend amount increases over the corporate life-cycle. The factors which determine the payout decision over the corporate life-cycle specifically relate to the firm's investment opportunity set, the growth rate of the firm, the cost of external capital, and the agency costs associated with free-cash flow. Entirely inconsistent with the signalling models of dividends, which suggest that 'immature' firms pay dividends, the life-cycle model of dividends suggests that firms first pay a dividend, and continue to do so when they reach 'maturity'. 'Mature firms are characterised as those whose internally-generated funds are more than sufficient to meet their diminished investment opportunity set, have lower and more stable growth rates, are profitable, but have positive and increasing free cash flow. For mature firms, dividends serve to reduce the agency costs of free cash flow (Jensen, 1986; Easterbrook, 1984). In stark contrast, internal funds are not sufficient to meet the investment needs of fast-growing, unprofitable 'immature' firms. For these firms, there is neither the funds 
available, nor the necessity from an agency perspective (no agency costs of free cash flow) to pay a dividend. In summary, according to the life-cycle model of dividends, and all else equal, 'mature' firms initiate and continue to pay dividends; 'immature' firms do not. $^{2}$

The outcome and substitution models of dividends are theoretically grounded in Jensen's (1986) free cash flow hypothesis. Both models agree that dividends paid to shareholders serve to reduce agency costs. In the case of the outcome model, dividends paid to shareholders serve to reduce the agency costs of free cash flow. ${ }^{3}$ In the case of the substitution model, dividends paid serve to substitute for poor governance, and hence serve to reduce the agency costs of poor quality governance (as opposed to free cash flow). However, they disagree on one crucial point, namely the direction of the relationship between the strength of corporate governance and the likelihood of paying a dividend and the dividend amount (payout). Let's elaborate further. Both begin with the premise that given free cash flow, shareholders (outsiders) prefer dividends to retained earnings, since expropriation of free cash flow by self-serving insiders is value-decreasing for minority shareholders. On the one hand, the outcome model suggests that the ability on the part of shareholders to force firms to pay dividends rests crucially on the efficiency of the corporation's governance system. Thus, the outcome model predicts that the likelihood of paying a dividend and the dividend amount (payout) increases when free cash flow exists and where shareholder rights are strong (Chae et al., 2009). ${ }^{4,5}$ Numerous studies have found support in favour of the outcome model using either shareholder rights measured at the firm (corporate governance) or country level, or both (e.g., Mitton, 2004; Chae et al., 2009; Jiraporn et al., 2011; Adjaoud and Ben-Amar, 2010; Bartram et al., 2012; Brockman and Unlu, 2009, 2011; Byrne and O'Connor, 2012; Shao et al., 2009; Sawicki, 2009) in post-Asian crisis Asia (Petrasek, 2012; Francis et al., 2011). ${ }^{6}$

On the other hand, the substitution model suggests otherwise. It predicts that poorly-governed firms, presumably with sizable agency conflicts, and wishing to enhance their reputation for equitable treatment of outsiders (presumably to raise external capital at lower cost) pay large dividends. In doing so these firms commit to fair treatment of their minority shareholders, not just in the current period, but also subsequent periods because dividend cuts are unlikely since they are costly. The very fact that these firms wish to access external capital at cheaper cost by paying reputationally-enhancing dividends implicitly implies that these firms are in the early stages of their life-cycle, since 'mature' firms, by definition, have internal funds which more than meets their investment needs. The substitution model suggests that better-governed firms, without the necessity to enhance their reputation, pay smaller dividends than their less well-governed counterparts. Consequently, the substitution model predicts that, all else equal, dividend payouts decrease in shareholder rights, and in contrast to the predictions of the outcome model, (poorly governed) firms voluntarily, rather than under duress from shareholders (of firms with efficient governance), pay large dividends. As is the case for the outcome model, there exists plenty of empirical support for the substitution model (e.g., John and Knyazeva, 2006; Officer, 2011; Jo and Pan, 2009; Jiraporn and Ning, 2006; Chae et al., 2009; Sawicki, 2009) in pre-Asian crisis Asia and Mitton (2004) in civil law countries only). ${ }^{7}$ Brockman and Unlu (2011) show that the substitution model prevails in countries where disclosure environments are opaque and the outcome model in countries where disclosure environments are transparent. Shao et al. (2009) and Byrne and O'Connor (2006) find support in favour of the substitution model where creditor rights are weak. 
From a theoretical viewpoint, there is no reason to suggest that the relationship between the strength of country and/or corporate governance and dividend payout is static i.e., does not change over time. In a dynamic setting, both Liu (2002) and O'Connor (2006) find support in favour of the outcome and substitution models of dividends. They show that dividend payouts are greatest when country (Liu, 2002), or corporate (O'Connor, 2006) governance is strong (i.e., the outcome model prevails), but changes in governance lead to lower dividends (i.e., the substitution model prevails). Liu (2002) finds that dividend payouts tend to be greatest in countries who score highly in variables which account for country-level governance (the outcome model), but country-level governance reforms (changes) are associated with lower dividends (the substitution model). O'Connor (2006) finds likewise, but instead uses corporate in place of country governance. He shows that exchange trading cross-listing Level 2/3 ADR firms substitute dividends for enhanced bonding, even though dividends remain higher in firms from countries with strong governance (the outcome model). Sawicki (2009) examines the agency models of dividends around the time of the Asian crisis. The substitution model prevails pre-crisis, while the outcome model prevails post-crisis.

Along similar lines, it is likely that the outcome and substitution models will prevail, but most likely, at different stages along the corporate life-cycle. For a number of reasons, the outcome model of dividends is much more likely to manifest when firms are 'mature'. First, the outcome model rests crucially on the prevalence of free cash flow, which is likely to be of much greater relevance for mature firms since internally generated cash is more than sufficient to fund their diminishing investment opportunities (see Grullon et al., 2002; DeAngelo et al., 2006; Denis and Osobov, 2008). In support, Chae et al. (2009) show that for US firms, the dividend amount increases in free cash flow and the strength of corporate governance. Second, the outcome model is much less likely to manifest for well-governed 'immature' firms, since the shareholders of these firms generally accept lower dividends given firm growth and external financing needs (see Mitton, 2004; Chae et al., 2009; Bartram et al., 2012). In contrast, the shareholders of poorly-governed firms do not. Third, the separation of ownership from control which results in agency conflicts (and costs) between managers and minority shareholders is likely to be much more prevalent in complex, large 'mature' organisations. In contrast, in smaller, younger 'immature' firms, managers are much more likely to have a large controlling stake in the firm, thus reducing agency conflicts, since their interests are likely to be much better aligned with outsiders. As a result, the need for dividends to reduce the agency costs of free cash flow is more relevant for 'mature' firms and less relevant for 'immature' firms. Hence the agency costs of free cash flow are likely to be more severe for 'mature' firms. This line of reasoning leads to the first testable hypothesis.

Hypothesis 1: The outcome model of dividends is more likely to prevail when firms are 'mature'.

The substitute model is likely to be much more relevant for 'immature' firms. Firms are much more likely to require external financing when they are young, 'immature', and with abundant growth opportunities. Since the costs of external financing are likely to be much higher for opaque, poorly-governed firms (see Chen et al., 2009); there is a much greater incentive on the part of these firms to build reputation by paying large dividends. Hence, immature, young, opaque, and poorly-governed firms, with a need for external 
financing, may seek to establish a reputation for fair treatment of their minority shareholders by paying a dividend even given negative free cash flow. This, in turn may serve to reduce their cost of capital. Since bonding mechanisms are few in emerging markets, the emergence of the substitution model when firms are immature is a viable possibility (Benos and Weisbach, 2004). In contrast, there is much less of an incentive on the part of better-governed firms to follow suit since their cost of capital is likely to be much lower, and, as already alluded to, the shareholders of these firms do not demand large dividends given firm growth and external financing needs (see Mitton, 2004; Chae et al., 2009; Bartram et al., 2012). This leads to the second testable hypothesis.

Hypothesis 2: The substitution model of dividends is likely to prevail when firms are young and 'immature'.

\section{Data}

In this paper I examine the relationship between the strength of corporate governance and corporate dividend policy in emerging markets along the corporate life-cycle. ${ }^{8}$ To measure the strength of corporate governance, I follow Mitton (2004) and others (see for example, Klapper and Love, 2004; Durnev and Kim, 2005; Chen et al., 2009), and use the corporate governance scores developed by Credit Lyonnais Securities Asia (CLSA, 2001). The CLSA governance ratings range from a low of 0 to a high of 100 with higher values suggesting better quality corporate governance. The rating for each individual firm, for which there is 495 in total across 25 countries, is a composite measure of 57 qualitative, binary questions which span seven distinct governance categories, namely management discipline, transparency, independence, accountability, responsibility, fairness, and social awareness. The first six governance provisions have a $15 \%$ weighting in the composite index, while social awareness has a $10 \%$ weighting. The rating for each firm is constructed by CLSA analysts. In this paper, I use the first six governance provisions to construct the composite governance measure, with each given equal weighting, since dividend payout is unlikely to be related to social awareness. I use three different dividend payout measures, namely dividends-to-earnings (\%), dividends-to-cashflow (\%), and dividends-to-sales (\%). ${ }^{9}$ All data is sourced from Worldscope at year end 2001. In all regressions, I control for firm size, firm profitability, firm growth, cash holdings, total equity and retained equity. Size and profitability are expected to impact positively on dividend policy. In contrast, high growth firms typically pay smaller dividends. ${ }^{10}$ The expected relationship between cash holdings and dividend payout is ambiguous. Firms with high cash reserves but with little or no demand for external finance are likely to pay a dividend. In contrast, firms with anticipated future growth opportunities may finance their growth with their cash reserves, and refrain from paying a dividend. I proxy for the firms maturity or position along its life-cycle by using either earned equity (retained earnings) to book assets (RE/TA) or earned equity (retained earnings) to total equity (RE/TE) (see DeAngelo et al., 2006; Denis and Osobov, 2008; Brockman and Unlu, 2011). DeAngelo et al. (2006), Denis and Osobov (2008) and Brockman and Unlu (2011) all show that dividend payout increases in RE/TA (and RE/TE), since as firms mature, the contribution of earned equity (relative to contributed equity) to total equity (and total assets) increases, since firms become more 
profitable and have a reduced investment opportunity set, reducing the need for external (contributed) capital, which ultimately results in free cash flow. Mature (Immature) firms are characterised with high (low) ratios of retained equity to total assets and retained equity to total equity. Total equity (to total assets) is included as an additional control in the dividend regressions, so that the impact of total equity financing (TE) is not confounded with the effect of the composition of equity financing (RE) on dividend payout (See DeAngelo et al., 2006). All financial firms and firm observations with missing or abnormal data i.e., firms with negative earnings, negative total assets, and negative cashflow are eliminated. All firm level variables are winsorised at the 1st and 99 th percentiles.

I include two country-level determinants of dividend policy, namely shareholder and creditor rights. The early literature suggests that dividends can be an outcome of, or substitute for, shareholder rights. More recent work incorporates the agency costs of debt (i.e., the conflict between shareholders and creditors) and estimates the joint effect of shareholder and creditor rights on corporate dividend policy (see Brockman and Unlu, 2009; Shao et al., 2009; Byrne and O'Connor, 2012). I use the revised version of the anti-director rights measure from Spamann (2010) to account for the strength of shareholder rights at the country-level. Since this data is missing for China, Hungary, and Poland, I use the Djankov et al. (2008) measure of shareholder rights for these countries. Higher values reflect better shareholder protection. The creditor rights measure is from Djankov et al. (2007) and ranges from a low of zero to a high of four, where higher values represent greater levels of creditor protection. A description of the variables employed in this paper is provided in Appendix 1.

Table 1 presents descriptive statistics of the main data items of interest by country. From my original sample, I lose 275 firms since some or all of the firm-level control variables are missing for these firms, resulting in a final sample of 220 publicly-traded firms (see Column labelled '\# Firm 1'). ${ }^{11}$ These 220 firms come from 21 countries, namely Argentina, Brazil, Chile, China, Colombia, Hong Kong, Hungary, India, Indonesia, Korea (Republic), Malaysia, Mexico, Pakistan, Peru, Philippines, Poland, Singapore, South Africa, Taiwan, Thailand, and Turkey. The number of firms varies considerably by country. Taiwan (31 firms) followed by Hong Kong (25) and Malaysia (22) supply the largest number of firms. In contrast, there is just a single firm from Argentina, Colombia, Hungary, and Peru in the final sample of firms. The fourth, fifth and sixth columns of Table 1 contain the mean, median and standard deviation corporate governance score by country. The median firm is best-governed in Peru (76.5), Singapore (67.4), and Argentina (66.7). In contrast, the median firm is poorly governed in Pakistan (33.6) and Poland (37.7). ${ }^{12}$ Interestingly, while the median firm from Pakistan has the lowest governance score of all firms in the sample, the greatest variation in governance scores occurs in Pakistan (standard deviation is 20.2). Hence, there are firms in Pakistan which are much better governed than their median counterpart. There is much less variation in corporate governance practices in Mexico (standard deviation is 4.0), Chile (4.2), and Korea (5.8). Overall, the median firm has a corporate governance score of 55.8, with a standard deviation of 14.6. ${ }^{13}$ The average firm is best governed in Peru (76.5), followed closely by firms from Singapore (69.2) and Mexico (66.8). The average firm is least well-governed in Poland (37.7). ${ }^{14}$ 
Table 1 Sample description

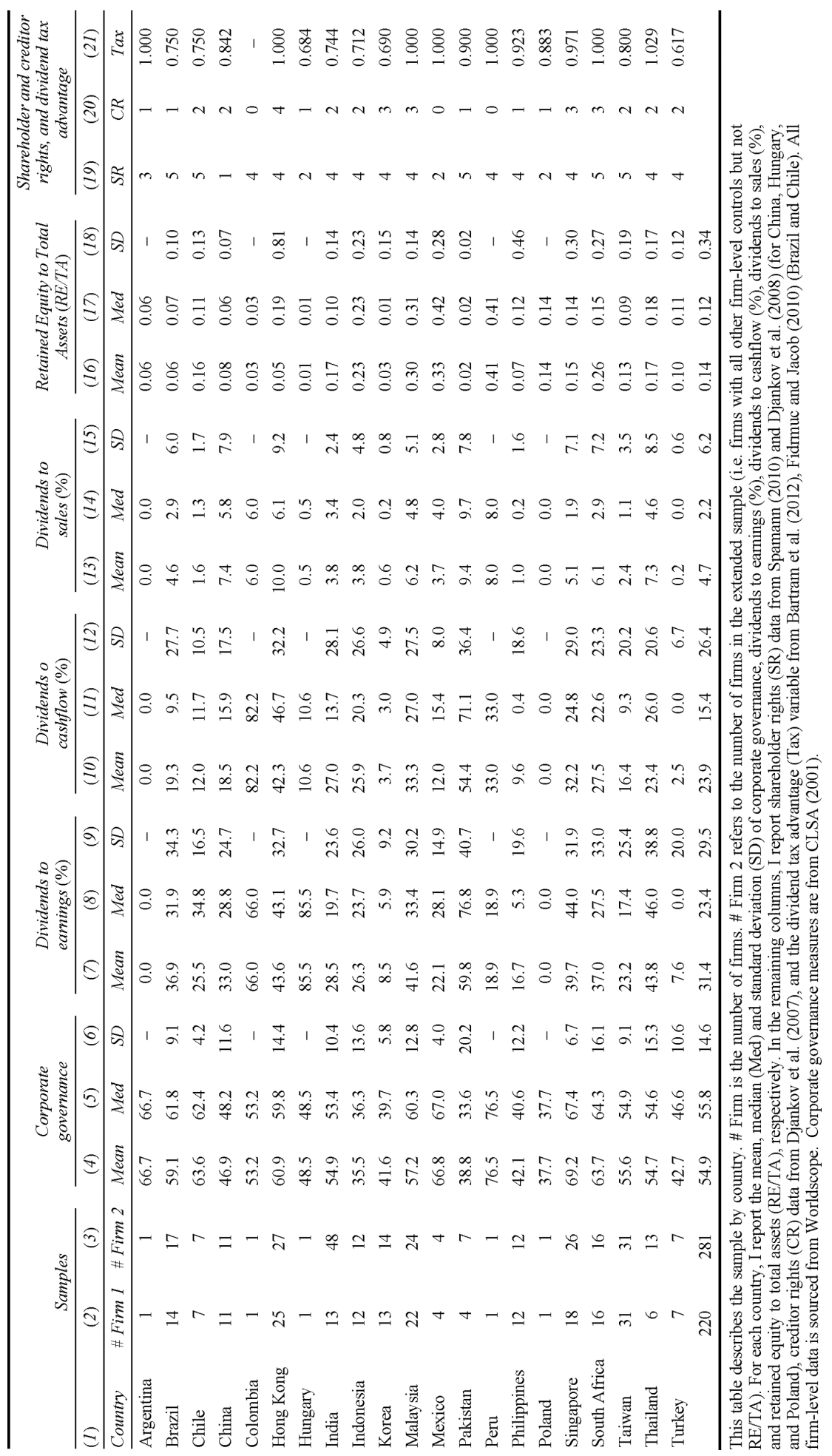


In columns $7-15$, I outline the mean, median and standard deviation dividend payout by country, using all three dividend payout measures. They suggest that as a percentage of earnings, the median firm in Hungary (85.5\%) and Pakistan $(76.8 \%)$ pay the largest dividends. Dividend payouts tend to be much lower in the Philippines (5.3\%) and Korea (5.9\%). The sole firms from Argentina and Poland pay no dividend at all in 2001. When using either cashflow or sales, dividend payouts tend to be high in Colombia (median dividends to cashflow (\%) and dividends to sales (\%) is $82.2 \%$ and $6.0 \%$, respectively), and Pakistan (median dividends to cashflow (\%) and dividends to sales (\%) is $71.1 \%$ and $9.7 \%$, respectively). The median firm pays much lower dividends in Brazil (median dividends to cashflow (\%) and dividends to sales (\%) are $9.5 \%$ and $2.9 \%$, respectively), Korea (median dividends to cashflow (\%) and dividends to sales (\%) are $3.0 \%$ and $0.2 \%$, respectively), and Taiwan (median dividends to cashflow (\%) and dividends to sales (\%) are $9.3 \%$ and $1.1 \%$, respectively). In the full sample, the median firm pays $23.4 \%, 15.4 \%$, and $2.2 \%$, of its earnings, cashflow, or sales, respectively, in the form of a dividend. Average dividend payouts relative to earnings, cashflow, and sales are greatest in Hungary (85.5), Colombia (82.2), and Hong Kong (10.0), respectively. ${ }^{15}$

The mean, median and variation in retained equity to total assets (RE/TA) are presented in columns 16-18 of Table 1. Retained equity, relative to either total assets or total equity (unreported), is much higher in Mexico (the median retained equity to total assets (total equity) is $0.42(0.98)$ ), Peru ( 0.41 and 0.52 , respectively), and Hong Kong ( 0.19 and 0.45 , respectively). In contrast, retained equity is much lower in Colombia (the median retained equity to total assets (total equity) is $0.03(0.05)$ ), Hungary ( 0.01 and 0.01 , respectively), and Korea ( 0.01 and 0.01 , respectively). These figures suggest that there is considerable heterogeneity in terms of firm maturity across the sample of firms. The median firm has retained equity, scaled by either total assets or total equity, of 0.12 and 0.27 , respectively. The average firm tends to be most mature in Peru (RE/TA is 0.41 ), and the least mature in Hungary (RE/TA is 0.01 ).

Columns 19 and 20 of Table 1 suggest that country-level shareholder protection is highest in Brazil, Pakistan, South Africa and Taiwan (all have a shareholder rights measure of 5), and the lowest in China (Shareholder rights score of 1). Creditor protection is strongest in Hong Kong (Score of 4), and the weakest in Colombia and Mexico (Both have creditor rights scores of 0) (see columns 19 and 20 of Table 1). A priori, the sign on the shareholder and creditor rights variables are expected to be positive.

\section{Methodology}

In this section I begin by examining the relationship between the strength of corporate governance and dividend payout. Then I proceed to examine this aforementioned relationship separately for firms at different stages of the corporate life-cycle. I end by examining these same relationships by the strength of creditor rights.

I begin by estimating Ordinary Least Squares (OLS) regressions of the following form:

$$
\begin{aligned}
\mathrm{DIV}_{i}= & \alpha+\beta_{1} \mathrm{GOV}_{i}+\beta_{2} \text { Size }_{i}+\beta_{3} \mathrm{Growth}_{i}+\beta_{4} \text { Profitability }_{i}+\beta_{5} \mathrm{Cash}_{i} \\
& +\beta_{6} \mathrm{TE}_{i}+\beta_{7} \mathrm{RE}_{i}+\text { Industry }_{i}+\text { Country }_{c}+\varepsilon_{i}
\end{aligned}
$$




$$
\begin{aligned}
\mathrm{DIV}_{i}= & \alpha+\beta_{1} \mathrm{GOV}_{i}+\beta_{2} \text { Size }_{i}+\beta_{3} \text { Growth }_{i}+\beta_{4} \text { Profitability }_{i}+\beta_{5} \text { Cash }_{i} \\
& +\beta_{6} \mathrm{TE}_{i}+\beta_{7} \mathrm{RE}_{i}+\beta_{8} \mathrm{SR}_{c}+\beta_{9} \mathrm{CR}_{c}+\text { Industry }_{i}+\varepsilon_{i}
\end{aligned}
$$

where $\mathrm{DIV}_{\mathrm{i}}$ is either dividends-to-earnings (\%), dividends-to-cashflow (\%), or dividends-to-sales (\%), and $\mathrm{GOV}_{i}$ is the CLSA corporate governance score for each firm. Size, growth, profitability, cash, TE, and RE, are firm size, firm growth, firm profitability, firm cash, firm total equity, and firm retained eaquity (to total assets or total equity), respectively. Industry ${ }_{i}$ are industry dummies, Country ${ }_{C}$ country dummies, and $\mathrm{SR}_{C}$ and $\mathrm{CR}_{C}$, shareholder and creditor rights, respectively. ${ }^{16}$ In equation (2), country dummies are excluded when shareholder and creditor rights are included. All regressions are estimated with White (1980) heteroscedastic-consistent standard errors. The coefficient estimates from estimating equations (1) and (2) are presented in Table 2.

\begin{tabular}{|c|c|c|c|c|c|c|}
\hline & \multicolumn{6}{|c|}{ Dividend payout measure } \\
\hline & \multicolumn{2}{|c|}{$\begin{array}{l}\text { Dividends to } \\
\text { earnings }(\%)\end{array}$} & \multicolumn{2}{|c|}{$\begin{array}{l}\text { Dividends to } \\
\text { cashflow (\%) }\end{array}$} & \multicolumn{2}{|c|}{$\begin{array}{c}\text { Dividends to } \\
\text { sales }(\%)\end{array}$} \\
\hline \multicolumn{7}{|c|}{ Ordinary least squares } \\
\hline $\begin{array}{l}\text { Corporate } \\
\text { governance }\end{array}$ & $\begin{array}{c}0.369 * * \\
(2.20)\end{array}$ & $\begin{array}{c}0.438 * * * \\
(3.44)\end{array}$ & $\begin{array}{l}0.270^{*} \\
(1.91)\end{array}$ & $\begin{array}{c}0.340 * * * \\
(3.05)\end{array}$ & $\begin{array}{c}0.070 * * \\
(2.12)\end{array}$ & $\begin{array}{c}0.071 * * * \\
(2.86)\end{array}$ \\
\hline Size & $\begin{array}{l}1.862 \\
(1.08)\end{array}$ & $\begin{array}{l}1.554 \\
(1.04)\end{array}$ & $\begin{array}{l}0.615 \\
(0.42)\end{array}$ & $\begin{array}{l}0.219 \\
(0.18)\end{array}$ & $\begin{array}{l}0.547 * \\
(1.66)\end{array}$ & $\begin{array}{l}0.442 * \\
(1.68)\end{array}$ \\
\hline Growth & $\begin{array}{c}-29.690 * * \\
(2.06)\end{array}$ & $\begin{array}{c}-27.235^{* *} \\
(2.18)\end{array}$ & $\begin{array}{l}2.691 \\
(0.22)\end{array}$ & $\begin{array}{l}2.893 \\
(0.27)\end{array}$ & $\begin{array}{l}-3.065 \\
(1.02)\end{array}$ & $\begin{array}{l}-2.359 \\
(0.91)\end{array}$ \\
\hline Profitability & $\begin{array}{l}18.308 \\
(0.80)\end{array}$ & $\begin{array}{l}8.653 \\
(0.48)\end{array}$ & $\begin{array}{l}26.156 \\
(1.49)\end{array}$ & $\begin{array}{l}20.806 \\
(1.42)\end{array}$ & $\begin{array}{c}12.467 * * * \\
(3.04)\end{array}$ & $\begin{array}{c}10.816^{* * *} \\
(2.88)\end{array}$ \\
\hline Cash & $\begin{array}{l}8.099 \\
(0.44)\end{array}$ & $\begin{array}{l}9.541 \\
(0.57)\end{array}$ & $\begin{array}{l}7.611 \\
(0.52)\end{array}$ & $\begin{array}{l}11.278 \\
(0.86)\end{array}$ & $\begin{array}{l}3.731 \\
(0.97)\end{array}$ & $\begin{array}{l}4.354 \\
(1.19)\end{array}$ \\
\hline Total equity & $\begin{array}{l}15.975 \\
(1.11)\end{array}$ & $\begin{array}{c}20.804 \\
(1.56)\end{array}$ & $\begin{array}{l}8.712 \\
(0.67)\end{array}$ & $\begin{array}{l}13.970 \\
(1.21)\end{array}$ & $\begin{array}{c}8.893 * * * \\
(3.10)\end{array}$ & $\begin{array}{c}8.897 * * * \\
(3.48)\end{array}$ \\
\hline $\begin{array}{l}\text { Retained } \\
\text { equity }\end{array}$ & $\begin{array}{c}16.864 * * \\
(2.46)\end{array}$ & $\begin{array}{c}13.471^{* *} \\
(2.15)\end{array}$ & $\begin{array}{l}9.548 \\
(1.51)\end{array}$ & $\begin{array}{l}5.821 \\
(1.03)\end{array}$ & $\begin{array}{l}0.475 \\
(0.49)\end{array}$ & $\begin{array}{l}0.214 \\
(0.23)\end{array}$ \\
\hline $\begin{array}{l}\text { Shareholder } \\
\text { rights }\end{array}$ & & $\begin{array}{l}-0.485 \\
(0.21)\end{array}$ & & $\begin{array}{l}0.382 \\
(0.24)\end{array}$ & & $\begin{array}{l}-0.425 \\
(0.97)\end{array}$ \\
\hline Creditor rights & & $\begin{array}{l}1.588 \\
(0.69)\end{array}$ & & $\begin{array}{l}3.004 \\
(1.46)\end{array}$ & & $\begin{array}{l}0.475 \\
(1.08)\end{array}$ \\
\hline \# Firms & 220 & 220 & 220 & 220 & 220 & 220 \\
\hline $\begin{array}{l}\text { Country } \\
\text { dummies }\end{array}$ & Yes & No & Yes & No & Yes & No \\
\hline $\begin{array}{l}\text { Industry } \\
\text { dummies }\end{array}$ & Yes & Yes & Yes & Yes & Yes & Yes \\
\hline$R$-squared & 0.388 & 0.306 & 0.457 & 0.390 & 0.508 & 0.448 \\
\hline
\end{tabular}

Table 2 Regression estimates 
Table 2 Regression estimates (continued)

\begin{tabular}{lcccccc}
\hline \multicolumn{7}{c}{ Dividend payout measure } \\
\cline { 2 - 7 } & \multicolumn{2}{c}{$\begin{array}{c}\text { Dividends to } \\
\text { earnings (\%) }\end{array}$} & $\begin{array}{c}\text { Dividends to } \\
\text { cashflow }(\%)\end{array}$ & $\begin{array}{c}\text { Dividends to } \\
\text { sales }(\%)\end{array}$ \\
\hline $\begin{array}{l}\text { Weighted least squares } \\
\text { Corporate } \\
\text { governance }\end{array}$ & $0.456^{* *}$ & $0.382^{* *}$ & $0.387^{* *}$ & $0.311^{* * *}$ & $0.093^{* * *}$ & $0.063^{* *}$ \\
\# Firms & $(2.35)$ & $(2.32)$ & $(2.56)$ & $(2.70)$ & $(2.97)$ & $(2.57)$ \\
$\begin{array}{l}\text { Country } \\
\text { dummies }\end{array}$ & 220 & 220 & 220 & 220 & 220 & 220 \\
$\begin{array}{l}\text { Industry } \\
\text { dummies }\end{array}$ & Yes & No & Yes & No & Yes & No \\
$R$-squared & 0.594 & 0.403 & 0.640 & 0.517 & 0.591 & 0.475 \\
\hline
\end{tabular}

This table reports coefficient estimates from ordinary and weighted least squares regressions with heteroscedastic consistent $t$-stats presented underneath in parenthesis. The coefficient estimates from the ordinary (weighted) least squares regressions are presented in the top (bottom) panel. In the weighted least squares regressions, the weight of each observation (firm) is the inverse of the number of observations (firms) in each country. The sample period is for the year 2001. The dependent variable is dividends to earnings (\%), dividends to cashflow (\%), and dividends to sales $(\%)$, as indicated. All other variables are defined in the main text and in Appendix 1. Shareholder rights data is from Spamann (2010) and Djankov et al. (2008) (for China, Hungary, and Poland), and creditor rights data is from Djankov et al. (2007). All firm-level data is sourced from Worldscope. Corporate governance measures are from CLSA (2001). A full-set of country and industry dummies are included where indicated, but not reported. \# Firms is the number of firms, and *,**, and *** denotes significance at the $10 \%, 5 \%$, and $1 \%$ level, respectively.

\section{Results}

The findings presented in Table 2 are in line with Mitton (2004), and others, and provide support in favour of the outcome model of dividends. The coefficient estimates on the corporate governance variable are always positive and statistically different to zero. They range from a low of $0.07(t=2.12 ; p<0.05)$ (using dividends to sales $(\%))$ to a high of $0.438(t=3.44 ; p<0.01)$ using dividends to earnings $(\%){ }^{17}$ These coefficient estimates imply that a one standard deviation change in corporate governance (14.6), which is close to the difference in the median corporate governance score for firms from India (53.4) and Singapore (67.4), changes dividend payout by 6.39 percentage points using dividends to earnings $(\%)(0.438 \times 14.6), 4.96$ percentage points using dividends to cashflow $(\%)(0.340 \times 14.6)$, and 1.037 percentage points using dividends to sales $(\%)$ $(0.071 \times 14.6)$. While not always statistically significant, the firm-level control variables are of the correct sign. Large and profitable firms pay higher dividends. Growth firms tend to pay lower dividends. Furthermore, and consistent with the life-cycle model of dividends, dividend payout (at least using dividends to earnings (\%)) increases with corporate maturity i.e., when the ratio of retained equity to total assets increases. ${ }^{18}$ 
I find no evidence to suggest that corporate dividend payouts increase in country-level shareholder and creditor rights. ${ }^{19}$ This contradicts the evidence presented in La Porta et al. (2000) and Mitton (2004) in the case of shareholder rights, and Brockman and Unlu (2009), Shao et al. (2009), Byrne and O'Connor (2012) in the case of creditor rights. The latter three all highlight the profound influence that creditors have, over and above shareholders, in determining corporate dividend payout.

In the remaining rows of Table 2, I address the concern that the results are driven by the large number of observations provided by some countries. To address this concern, I estimate equations (1) and (2) using weighted least squares, where the weight of each observation (firm) is the inverse of the number of observations in each country, so that each country receives an equal weighting in the estimation. When I do so, the general conclusions remain unaltered. Dividend payouts remain an outcome of effective corporate governance. The coefficient estimates on the corporate governance variable remain positive and are always statistically significant. ${ }^{20}$

In summary, the findings are consistent with Mitton (2004), and many others, and provide support for the outcome model of dividends. Shareholders use their legal rights, in this instance measured at the firm-level, to extract large dividends from firms. All else equal, dividend payouts are greater in better governed firms. Next, I examine whether this relationship changes along the corporate life-cycle.

\subsection{Results by stage of corporate life-cycle}

To do so, I sub-divide my original sample of firms by level of retained equity (either to total assets or total equity) and re-estimate equation 1 for each sub-sample of firms. Using the original sample of 220 firms, I create two groups of firms, divided at the sample median of RE/TA (and RE/TE). Thus, each group has 110 firms each. Equation (1) is estimated separately for both sets of firms and the coefficient estimates are presented in Table 3. All firm, industry, and country controls are included, but not reported. Table 3 suggests that the outcome model prevails, but only at the later stage of the corporate life-cycle, since the coefficient estimates on the corporate governance variable is only positive and statistically significant in the regressions estimated for 'mature' firms only i.e., with above-median RE/TA. ${ }^{21}$ Furthermore, in two of the three cases, the difference in the coefficient estimates of the corporate governance variable between 'mature' and 'immature' firms is statistically significant ( $t$-statistic is 2.39 ; $p<0.01$, and $1.78, p<0.10$, when dividend payout is dividends to earnings (\%) and dividends to sales (\%), respectively). ${ }^{22}$ The conclusions remain unaltered in the weighted least squares regressions.

These findings suggest that the outcome model holds, but only when firms are 'mature'. These results support Hypothesis 1, but not Hypothesis 2, since I find no evidence in support of the substitution model. Emerging market firms do not appear to substitute (large) dividends for poor governance. Finally, my results do not appear to be driven by the difference in the number of observations across countries, since the weighted least squares regressions also support the notion that the outcome model manifests, but only when firms are 'mature'. 
Table 3 Regression estimates by level of RE/TA

\begin{tabular}{|c|c|c|c|c|c|c|}
\hline & \multicolumn{6}{|c|}{ Dividend payout ratio } \\
\hline & \multicolumn{2}{|c|}{$\begin{array}{l}\text { Dividends to } \\
\text { earnings }(\%)\end{array}$} & \multicolumn{2}{|c|}{$\begin{array}{l}\text { Dividends to } \\
\text { cashflow (\%) }\end{array}$} & \multicolumn{2}{|c|}{$\begin{array}{l}\text { Dividends to } \\
\text { sales }(\%)\end{array}$} \\
\hline & \multicolumn{2}{|c|}{ Life-cycle stage } & \multicolumn{2}{|c|}{ Life-cycle stage } & \multicolumn{2}{|c|}{ Life-cycle stage } \\
\hline & $\begin{array}{l}\text { Low RE/TA } \\
\text { (Immature) }\end{array}$ & $\begin{array}{c}\text { High RE/TA } \\
\text { (Mature) }\end{array}$ & $\begin{array}{l}\text { Low RE/TA } \\
\text { (Immature) }\end{array}$ & $\begin{array}{c}\text { High RE/TA } \\
\text { (Mature) }\end{array}$ & $\begin{array}{l}\text { Low RE/TA } \\
\text { (Immature) }\end{array}$ & $\begin{array}{c}\text { High RE/TA } \\
\text { (Mature) }\end{array}$ \\
\hline \multicolumn{7}{|c|}{ Ordinary least squares } \\
\hline Corporate & 0.241 & $0.392 *$ & 0.164 & 0.285 & 0.010 & $0.170 * * *$ \\
\hline governance & $(0.84)$ & $(1.87)$ & $(0.70)$ & $(1.18)$ & $(0.01)$ & $(3.26)$ \\
\hline \# Firms & 110 & 110 & 110 & 110 & 110 & 110 \\
\hline Controls & Yes & Yes & Yes & Yes & Yes & Yes \\
\hline $\begin{array}{l}\text { Country } \\
\text { dummies }\end{array}$ & Yes & Yes & Yes & Yes & Yes & Yes \\
\hline $\begin{array}{l}\text { Industry } \\
\text { dummies }\end{array}$ & Yes & Yes & Yes & Yes & Yes & Yes \\
\hline \multirow[t]{3}{*}{$R$-squared } & 0.605 & 0.516 & 0.592 & 0.516 & 0.538 & 0.557 \\
\hline & \multicolumn{6}{|c|}{ Tests of significance ( $t$-test) } \\
\hline & \multicolumn{2}{|c|}{$2.39 * * *$} & \multicolumn{2}{|c|}{0.88} & \multicolumn{2}{|c|}{$1.78 *$} \\
\hline \multicolumn{7}{|c|}{ Weighted least squares } \\
\hline Corporate & 0.491 & $0.322 *$ & 0.408 & $0.331 *$ & 0.054 & $0.192 * * *$ \\
\hline governance & $(1.42)$ & $(1.67)$ & $(1.45)$ & $(1.65)$ & $(0.92)$ & $(4.20)$ \\
\hline \# Firms & 110 & 110 & 110 & 110 & 110 & 110 \\
\hline Controls & Yes & Yes & Yes & Yes & Yes & Yes \\
\hline $\begin{array}{l}\text { Country } \\
\text { dummies }\end{array}$ & Yes & Yes & Yes & Yes & Yes & Yes \\
\hline $\begin{array}{l}\text { Industry } \\
\text { dummies }\end{array}$ & Yes & Yes & Yes & Yes & Yes & Yes \\
\hline \multirow[t]{3}{*}{$R$-squared } & 0.770 & 0.680 & 0.782 & 0.588 & 0.628 & 0.665 \\
\hline & \multicolumn{6}{|c|}{ Tests of significance ( $t$-test) } \\
\hline & \multicolumn{2}{|c|}{$1.98 * *$} & \multicolumn{2}{|c|}{0.30} & \multicolumn{2}{|c|}{$1.66^{*}$} \\
\hline
\end{tabular}

This table reports coefficient estimates from ordinary and weighted least squares regressions with heteroscedastic consistent $t$-stats presented underneath in parenthesis. In the weighted least squares regressions, the weight of each observation (firm) is the inverse of the number of observations (firms) in each country. The sample period is for the year 2001. Separate regressions are estimated for firms with high (above-median) and low (below-median) retained equity to total assets (RE/TA). The dependent variable is dividends to earnings (\%), dividends to cashflow (\%), and dividends to sales (\%), as indicated. A full set of firm-level controls (Controls), country and industry dummies are included, but not reported. All firm-level data is sourced from Worldscope. Corporate governance measures are from CLSA (2001). \# Firms is the number of firms, and $*, * *$, and $* * *$ denotes significance at the $10 \%, 5 \%$, and $1 \%$ level, respectively. The significance tests ( $t$-statistic) test whether the coefficient estimates on the corporate governance variable is statistically different in different stages of the corporate life-cycle. The test-statistic is calculated by estimating the following regression and testing the statistical significance of $\beta_{2}$. High RE/TA equals 1 if RE/TA is above the sample median, and zero otherwise.

$$
\begin{aligned}
\mathrm{DIV}_{i}= & \alpha+\beta_{1} \mathrm{GOV}_{i}+\beta_{2} \mathrm{GOV}_{i} \times \text { High RE}_{\mathrm{TA}}+\beta_{3} \text { Size }_{i}+\beta_{4} \text { Growth }_{i}+\beta_{5} \text { Profitability }_{i} \\
& +\beta_{6} \mathrm{Cash}_{i}+\beta_{7} \mathrm{TE}_{i}+\beta_{8} \mathrm{High} \mathrm{RE} / \mathrm{TA}_{i}+\text { Industry }_{i}+\text { Country }_{c}+\varepsilon_{i}
\end{aligned}
$$




\subsection{Results by stage of corporate life-cycle and strength of creditor rights}

Next, I examine whether shareholders in mature well-governed firms are still able to extract large dividends from firms when creditor rights are weak. I do so, since recent work suggests that creditors exert a greater influence over corporate dividend payout than do shareholders (see Brockman and Unlu, 2009; Shao et al., 2009; Byrne and O'Connor, 2012). Their collective work shows that the outcome model of dividends, inclusive of the agency costs of equity and debt, is contingent on strong shareholder and creditor rights. ${ }^{23}$ Where creditor rights are weak, creditors demand presumably by way of debt covenants, and firms consent, to pay lower dividends, in spite of strong shareholder rights (Smith and Warner, 1979; Kalay, 1982). Where creditor rights are strong, creditors consent to larger dividend payouts, but only in instances where shareholder rights are strong (Shao et al., 2009).

If the same holds true here in this analysis, and there is no reason to expect otherwise, then a priori, I would expect that the coefficient estimate on the corporate governance variable to be large when creditor rights are strong and firms mature, and much smaller for mature firms in countries where creditor rights are weak. Hence, the shareholders of better-governed firms may not be able to extract large dividends if creditor rights are weak. This is unlikely to be a real concern for shareholders of firms in Malaysia (Median (Mean) corporate governance is 60.3 (57.2) and creditor rights is 3), South Africa (Median (Mean) corporate governance is 64.3 (63.7) and creditor rights is 3), and Singapore (Median (Mean) corporate governance is 67.4 (69.2) and creditor rights is 3) since the median firm tends to be well-governed in these countries and creditor rights strong. In contrast, the median (and mean) firm is well-governed in Brazil (median and mean governance is 61.8 and 59.1, respectively), but creditor rights weak (1) (see Table 1).

In Table 4, I estimate equation 1 now by firm maturity and strength of creditor rights. ${ }^{24}$ The top panel contains the coefficient estimates for the high RE/TA group of firms, and the bottom panel the low RE/TA firms. ${ }^{25}$ The coefficient estimates suggest the following. When I sub-divide the mature firm sample by strength of creditor rights, and estimate equation (1) separately for each (i.e., above and below-median creditor rights), I find that the coefficient estimates on the corporate governance variable are positive for both sets of firms, but only statistically significant where creditor rights are strong. Where creditor rights are strong, the coefficient estimates on the corporate governance variable range from $0.206(t=3.69$; $p<0.01)$ (using dividends to sales $(\%))$ to $0.464(t=2.26, p<0.05)$ (using dividends to earnings $(\%))$. Furthermore, when compared to instances in which creditor rights are weak, the coefficient estimate on the corporate governance variable are larger where creditor rights are strong, and the difference between the two is statistically significant ( $t$-statistic is $2.00 ; p<0.05$ using Dividends to Cashflow (\%) and $1.67 ; p<0.10$, using Dividends to Sales $(\%)) .{ }^{26}$ These findings suggest that for mature firms, dividends are an outcome of strong corporate governance and creditor rights. 
Table 4 Regression estimates by level of RE/TA and creditor rights

\begin{tabular}{|c|c|c|c|c|c|c|}
\hline & \multicolumn{6}{|c|}{ Dividend payout measure } \\
\hline & \multicolumn{2}{|c|}{$\begin{array}{l}\text { Dividends to } \\
\text { earnings }(\%)\end{array}$} & \multicolumn{2}{|c|}{$\begin{array}{l}\text { Dividends to } \\
\text { cashflow (\%) }\end{array}$} & \multicolumn{2}{|c|}{$\begin{array}{l}\text { Dividends to } \\
\text { sales }(\%)\end{array}$} \\
\hline & $\begin{array}{c}\text { Low } \\
\text { creditor }\end{array}$ & $\begin{array}{c}\text { High } \\
\text { creditor }\end{array}$ & $\begin{array}{c}\text { Low } \\
\text { creditor }\end{array}$ & $\begin{array}{c}\text { High } \\
\text { creditor }\end{array}$ & $\begin{array}{c}\text { Low } \\
\text { creditor }\end{array}$ & $\begin{array}{c}\text { High } \\
\text { creditor }\end{array}$ \\
\hline \multicolumn{7}{|c|}{ High RE/TA (Mature) } \\
\hline \multirow{2}{*}{$\begin{array}{l}\text { Corporate } \\
\text { governance }\end{array}$} & 0.176 & 0.388 & -0.072 & $0.464 * *$ & $0.102 * *$ & $0.206 * * *$ \\
\hline & $(0.55)$ & $(1.51)$ & $(0.23)$ & $(2.26)$ & $(2.19)$ & $(3.69)$ \\
\hline Controls & Included & Included & Included & Included & Included & Included \\
\hline $\begin{array}{l}\text { Country } \\
\text { dummies }\end{array}$ & No & No & No & No & No & No \\
\hline $\begin{array}{l}\text { Industry } \\
\text { dummies }\end{array}$ & Yes & Yes & Yes & Yes & Yes & Yes \\
\hline \# Firms & 52 & 58 & 52 & 58 & 52 & 58 \\
\hline \multirow[t]{3}{*}{$R$-squared } & 0.079 & 0.321 & 0.239 & 0.183 & 0.336 & 0.272 \\
\hline & \multicolumn{6}{|c|}{ Tests of significance ( $t$-test) } \\
\hline & \multicolumn{2}{|c|}{1.42} & \multicolumn{2}{|c|}{$2.00 * *$} & \multicolumn{2}{|c|}{$1.67 *$} \\
\hline \multicolumn{7}{|c|}{ Low RE/TA (Immature) } \\
\hline \multirow{2}{*}{$\begin{array}{l}\text { Corporate } \\
\text { governance }\end{array}$} & 0.087 & $0.976^{* * *}$ & 0.190 & $0.499 *$ & 0.010 & 0.036 \\
\hline & $(0.40)$ & $(2.86)$ & $(1.05)$ & (1.97) & $(0.11)$ & $(0.58)$ \\
\hline Controls & Included & Included & Included & Included & Included & Included \\
\hline $\begin{array}{l}\text { Country } \\
\text { dummies }\end{array}$ & No & No & No & No & No & No \\
\hline $\begin{array}{l}\text { Industry } \\
\text { dummies }\end{array}$ & Yes & Yes & Yes & Yes & Yes & Yes \\
\hline \# Firms & 74 & 36 & 74 & 36 & 74 & 36 \\
\hline \multirow[t]{3}{*}{$R$-squared } & 0.256 & 0.409 & 0.257 & 0.281 & 0.291 & 0.355 \\
\hline & \multicolumn{6}{|c|}{ Tests of significance ( $t$-test) } \\
\hline & \multicolumn{2}{|c|}{$2.45^{* * *}$} & \multicolumn{2}{|c|}{$2.06 * * *$} & \multicolumn{2}{|c|}{1.54} \\
\hline
\end{tabular}

This table reports coefficient estimates from ordinary least squares with heteroscedastic consistent $t$-stats presented underneath in parenthesis. The sample period is for the year 2001. Separate regressions are estimated for firms with high (above-median) and low (below-median) retained equity to total assets (RE/TA), domiciled in countries with high (above-median) and low (below-median) creditor rights. The dependent variable is dividends to earnings (\%), dividends to cashflow (\%), and dividends to sales (\%), as indicated. A full set of controls are included, but not reported. All firm-level data is sourced from Worldscope. Corporate governance measures are from CLSA (2001). \# Firms is the number of firms, and *,**, and *** denotes significance at the $10 \%, 5 \%$, and $1 \%$ level, respectively. The significance tests ( $t$-statistic) test whether the coefficient estimates on the corporate governance variable is statistically different in different creditor rights regimes (Above and below-median creditor rights). The test-statistic is calculated by estimating the following regression and testing the statistical significance of $\beta_{2}$. High Creditor equals 1 if creditor rights are greater than 2 , and zero otherwise.

$$
\begin{aligned}
\mathrm{DIV}_{i}= & \alpha+\beta_{1} \mathrm{GOV}_{i}+\beta_{2} \mathrm{GOV}_{i} \times \text { High Creditor }_{i}+\beta_{3} \text { Size }_{i}+\beta_{4} \text { Growth }_{i}+\beta_{5} \text { Profitability }_{i} \\
& +\beta_{6} \mathrm{Cash}_{i}+\beta_{7} \mathrm{TE}_{i}+\beta_{8} \mathrm{RE} \mathrm{TA}_{i}+\beta_{9} \text { High Creditor }_{i}+\text { Industry }_{i}+\varepsilon_{i}
\end{aligned}
$$


Next, I perform the same analysis, but now for 'immature' firms i.e., firms with below-median RE/TA. When I do so, I find support in favour of the outcome model, but only where creditor rights are strong. The coefficient estimates on the corporate governance variable are positive and statistically significant, but only where creditor rights are strong (Using dividends to earnings (\%) (Coefficient is $0.976 ; p<0.01$ ) and dividends to cashflow (\%) (Coefficient is $0.499 ; p<0.10)$ ). Where creditor rights are weak, the coefficient estimates on the corporate governance measure are much lower, and always statistically insignificant. ${ }^{27}$ Furthermore, the coefficient estimates on the corporate governance variable are significantly larger where creditor rights are strong.

\section{Robustness}

Next, I examine whether my findings are robust to;

- the inclusion of taxation in the dividend regressions

- the inclusion of the social awareness component of the CLSA corporate governance measure

- an alternative corporate life-cycle proxy

- to alleviate concerns in relation to sample selection bias, a larger sample size.

First, I begin by examining whether my findings are robust to the inclusion of a measure of the taxation of dividend income (relative to share repurchase income) in the dividend regressions. Since dividend and share repurchase income is typically tax differently both within and across countries, a priori, one would expect dividend payments to be lower where share repurchases are tax advantaged relative to dividend income, all else equal. In fact, there is ample evidence to suggest that this is the case (see La Porta et al., 2000). Like La Porta et al. (2000) and others (see Bartram et al., 2012), I include the tax advantage (disadvantage) of dividends variable in all regressions, which is measured as the after-tax value of one dollar paid out in dividends over the after-tax value of one dollar paid out in capital gains. I source this variable from Bartram et al. (2012) and Fidrmuc and Jacob (2010). ${ }^{28}$ In Table 1 (Column 21) the dividend tax advantage variable is outlined for all countries bar Colombia. Only in Thailand (1.029) is dividend income tax advantaged relative to capital gains income in 2001. In contrast, dividend income is tax disadvantaged in all other countries, with the exception of Argentina, Hong Kong, Malaysia, Mexico, Peru and South Africa, where dividend income is neither tax-advantaged nor disadvantaged relative to share repurchase income. The analysis presented in Table 5 suggests that my findings are robust to the inclusion of the dividend tax advantage variable. For example, using dividends to earnings (\%), dividend payout remains an outcome of effective governance (see column labelled (Full Sample), coefficient estimate is $0.383, t$-stat is $2.89 ; p<0.01$ ), and during all stages of the corporate life-cycle (see columns under (Life-Cycle Stage), $0.504, t$-stat is $2.70 ; p<0.01$ for 'immature' firms and $0.345, t$-stat is $1.67 ; p<0.10$, for 'mature' firms), but only where creditor rights are strong (see remaining columns of Table 5). For example, for 'mature' firms, the coefficient estimate on the corporate governance variable is 0.434 ( $t$-stat is $1.74 ; p<0.01)$ under strong creditor rights and -0.358 ( $t$-stat is 0.73$)$. 
The difference between these coefficient estimates is statistically significant $(t$-stat is $1.70 ; p<0.10) .{ }^{29}$ Interestingly, the dividend tax advantage variable is never statistically significant in any of the regressions, but always positive for 'mature' firms and negative for 'immature' firms. ${ }^{30}$

Table 5 Including dividend tax advantage

\begin{tabular}{|c|c|c|c|c|c|c|c|}
\hline & \multicolumn{7}{|c|}{ Dependent variable is dividends to earnings (\%) } \\
\hline & \multirow[b]{2}{*}{ Full sample } & \multicolumn{2}{|c|}{ Life-cycle stage } & \multicolumn{2}{|c|}{$\begin{array}{c}\text { High RE/TA } \\
\text { (Mature) }\end{array}$} & \multicolumn{2}{|c|}{$\begin{array}{l}\text { Low RE/TA } \\
\text { (Immature) }\end{array}$} \\
\hline & & $\begin{array}{l}\text { Low RE/TA } \\
\text { (Immature) }\end{array}$ & $\begin{array}{c}\text { High RE/TA } \\
\text { (Mature) }\end{array}$ & $\begin{array}{c}\text { High } \\
C R\end{array}$ & $\begin{array}{c}\text { Low } \\
C R\end{array}$ & $\begin{array}{c}\text { High } \\
C R\end{array}$ & $\begin{array}{c}\text { Low } \\
C R\end{array}$ \\
\hline \multicolumn{8}{|c|}{ Ordinary least squares } \\
\hline $\begin{array}{l}\text { Corporate } \\
\text { governance }\end{array}$ & $\begin{array}{c}0.383 * * * \\
(2.89)\end{array}$ & $\begin{array}{c}0.504 * * * \\
(2.70)\end{array}$ & $\begin{array}{l}0.345^{*} \\
(1.67)\end{array}$ & $\begin{array}{l}0.434 * \\
(1.74)\end{array}$ & $\begin{array}{c}-0.358 \\
(0.73)\end{array}$ & $\begin{array}{l}0.704 * \\
(1.78)\end{array}$ & $\begin{array}{l}0.147 \\
(0.64)\end{array}$ \\
\hline Size & $\begin{array}{l}1.363 \\
(0.91)\end{array}$ & $\begin{array}{c}4.699 * * \\
(2.22)\end{array}$ & $\begin{array}{c}-0.082 \\
(0.04)\end{array}$ & $\begin{array}{l}3.780 \\
(1.00)\end{array}$ & $\begin{array}{l}0.929 \\
(0.30)\end{array}$ & $\begin{array}{l}0.530 \\
(0.18)\end{array}$ & $\begin{array}{l}5.974 * \\
(2.00)\end{array}$ \\
\hline Growth & $\begin{array}{c}-28.627 * * \\
(2.26)\end{array}$ & $\begin{array}{l}11.839 \\
(0.68)\end{array}$ & $\begin{array}{c}-68.055^{* * *} \\
(4.32)\end{array}$ & $\begin{array}{c}-83.059^{* * *} \\
(5.10)\end{array}$ & $\begin{array}{c}-5.974 \\
(0.19)\end{array}$ & $\begin{array}{r}-0.643 \\
(0.05)\end{array}$ & $\begin{array}{c}40.248^{*} \\
(1.71)\end{array}$ \\
\hline Profitability & $\begin{array}{l}13.064 \\
(0.72)\end{array}$ & $\begin{array}{l}27.658 \\
(1.15)\end{array}$ & $\begin{array}{c}-21.918 \\
(0.99)\end{array}$ & $\begin{array}{c}-35.654 \\
(1.16)\end{array}$ & $\begin{array}{c}-45.197 \\
(1.11)\end{array}$ & $\begin{array}{l}46.589 \\
(1.38)\end{array}$ & $\begin{array}{c}63.168^{*} \\
(1.66)\end{array}$ \\
\hline Cash & $\begin{array}{l}8.701 \\
(0.52)\end{array}$ & $\begin{array}{l}24.470 \\
(0.99)\end{array}$ & $\begin{array}{l}10.502 \\
(0.56)\end{array}$ & $\begin{array}{l}52.761 \\
(1.09)\end{array}$ & $\begin{array}{l}2.095 \\
(0.07)\end{array}$ & $\begin{array}{l}21.011 \\
(0.67)\end{array}$ & $\begin{array}{l}15.252 \\
(0.36)\end{array}$ \\
\hline Total equity & $\begin{array}{l}18.823 \\
(1.39)\end{array}$ & $\begin{array}{c}30.263 * \\
(1.66)\end{array}$ & $\begin{array}{l}5.142 \\
(0.27)\end{array}$ & $\begin{array}{c}-10.258 \\
(0.41)\end{array}$ & $\begin{array}{l}30.865 \\
(0.89)\end{array}$ & $\begin{array}{c}-29.512 \\
(1.21)\end{array}$ & $\begin{array}{c}41.812 * \\
(1.89)\end{array}$ \\
\hline $\begin{array}{l}\text { Retained } \\
\text { equity }\end{array}$ & $\begin{array}{c}13.504 * * \\
(2.33)\end{array}$ & $\begin{array}{l}-4.216 \\
(0.84)\end{array}$ & $\begin{array}{l}-3.057 \\
(0.15)\end{array}$ & $\begin{array}{c}-21.110 \\
(0.66)\end{array}$ & $\begin{array}{c}36.854 * * \\
(2.20)\end{array}$ & $\begin{array}{l}5.699 \\
(1.13)\end{array}$ & $\begin{array}{c}-32.355^{* *} \\
(2.13)\end{array}$ \\
\hline $\begin{array}{l}\text { Shareholder } \\
\text { rights }\end{array}$ & $\begin{array}{l}-0.251 \\
(0.11)\end{array}$ & $\begin{array}{c}-1.682 \\
(0.52)\end{array}$ & $\begin{array}{c}-2.976 \\
(0.77)\end{array}$ & $\begin{array}{l}3.254 \\
(0.33)\end{array}$ & $\begin{array}{l}5.084 \\
(0.90)\end{array}$ & $\begin{array}{l}8.899 \\
(0.85)\end{array}$ & $\begin{array}{c}-1.359 \\
(0.32)\end{array}$ \\
\hline Creditor rights & $\begin{array}{l}1.112 \\
(0.48)\end{array}$ & $\begin{array}{l}-4.494 \\
(1.22)\end{array}$ & $\begin{array}{l}4.711 \\
(1.39)\end{array}$ & $\begin{array}{c}28.732 * * \\
(2.55)\end{array}$ & $\begin{array}{l}8.266 \\
(0.56)\end{array}$ & $\begin{array}{c}22.994 * \\
(1.94)\end{array}$ & $\begin{array}{c}-7.326 \\
(0.63)\end{array}$ \\
\hline $\begin{array}{l}\text { Dividend tax } \\
\text { advantage }\end{array}$ & $\begin{array}{l}24.039 \\
(1.41)\end{array}$ & $\begin{array}{c}-31.045 \\
(1.27)\end{array}$ & $\begin{array}{c}34.876 \\
(1.30)\end{array}$ & $\begin{array}{l}43.661 \\
(0.63)\end{array}$ & $\begin{array}{l}91.337 \\
(1.10)\end{array}$ & $\begin{array}{c}-67.799 \\
(1.28)\end{array}$ & $\begin{array}{c}-76.105 \\
(1.54)\end{array}$ \\
\hline \# Firms & 219 & 109 & 110 & 58 & 52 & 36 & 73 \\
\hline $\begin{array}{l}\text { Country } \\
\text { dummies }\end{array}$ & No & No & No & No & No & No & No \\
\hline $\begin{array}{l}\text { Industry } \\
\text { dummies }\end{array}$ & Yes & Yes & Yes & Yes & Yes & Yes & Yes \\
\hline \multirow[t]{3}{*}{$R$-squared } & 0.311 & 0.469 & 0.359 & 0.619 & 0.407 & 0.871 & 0.472 \\
\hline & & \multicolumn{6}{|c|}{ Tests of significance ( $t$-test) } \\
\hline & & \multicolumn{2}{|c|}{1.60} & \multicolumn{2}{|c|}{$1.70^{*}$} & \multicolumn{2}{|c|}{$1.92 *$} \\
\hline
\end{tabular}


Table 5 Including dividend tax advantage (continued)

\begin{tabular}{|c|c|c|c|c|c|c|c|}
\hline & \multicolumn{7}{|c|}{ Dependent variable is dividends to earnings $(\%)$} \\
\hline & \multirow[b]{2}{*}{ Full sample } & \multicolumn{2}{|c|}{ Life-cycle stage } & \multicolumn{2}{|c|}{$\begin{array}{c}\text { High RE/TA } \\
\quad \text { (Mature) }\end{array}$} & \multicolumn{2}{|c|}{$\begin{array}{l}\text { Low RE/TA } \\
\text { (Immature) }\end{array}$} \\
\hline & & $\begin{array}{l}\text { Low RE/TA } \\
\text { (Immature) }\end{array}$ & $\begin{array}{c}\text { High RE/TA } \\
\quad \text { (Mature) }\end{array}$ & $\begin{array}{c}\text { High } \\
\text { CR }\end{array}$ & $\begin{array}{c}\text { Low } \\
\text { CR }\end{array}$ & $\begin{array}{c}\text { High } \\
\text { CR }\end{array}$ & $\begin{array}{c}\text { Low } \\
\text { CR }\end{array}$ \\
\hline \multicolumn{8}{|c|}{ Weighted least squares } \\
\hline $\begin{array}{l}\text { Corporate } \\
\text { governance }\end{array}$ & $\begin{array}{c}0.389 * * \\
(2.40)\end{array}$ & $\begin{array}{c}0.612 * * * \\
(2.83)\end{array}$ & $\begin{array}{l}0.342 * \\
(1.66)\end{array}$ & $\begin{array}{l}0.467 * \\
(1.93)\end{array}$ & $\begin{array}{c}-0.128 \\
(0.24)\end{array}$ & $\begin{array}{l}0.627 \\
(1.54)\end{array}$ & $\begin{array}{l}0.233 \\
(0.85)\end{array}$ \\
\hline \# Firms & 219 & 109 & 110 & 58 & 52 & 36 & 73 \\
\hline Controls & Yes & Yes & Yes & Yes & Yes & Yes & Yes \\
\hline $\begin{array}{l}\text { Country } \\
\text { dummies }\end{array}$ & No & No & No & No & No & No & No \\
\hline $\begin{array}{l}\text { Industry } \\
\text { dummies }\end{array}$ & Yes & Yes & Yes & Yes & Yes & Yes & Yes \\
\hline \multirow[t]{3}{*}{$R$-squared } & 0.394 & 0.602 & 0.482 & 0.648 & 0.571 & 0.873 & 0.660 \\
\hline & & \multicolumn{6}{|c|}{ Tests of significance ( $t$-test) } \\
\hline & & \multicolumn{2}{|c|}{$1.67 *$} & \multicolumn{2}{|c|}{$2.09 * *$} & \multicolumn{2}{|c|}{1.45} \\
\hline
\end{tabular}

This table reports coefficient estimates from ordinary and weighted least squares regressions with heteroscedastic consistent $t$-stats presented underneath in parenthesis. The weight of each observation (firm) in the weighted least squares regressions is the inverse of the number of observations (firms) in each country. The sample period is for the year 2001. Separate regressions are estimated for the full sample of firms, for firms with high (above-median, 'mature') and low (below-median, immature') retained equity to total assets (RE/TA), and for 'mature' and 'immature' firms in countries with high (above-median i.e., creditor rights measure greater than 2) and low (below-median i.e., creditor rights measure less than and equal to 2) creditor rights. The dependent variable is dividends to earnings (\%). All firm-level data is sourced from Worldscope. Dividend Tax Advantage variable measures the after-tax value of one dollar paid out in dividends divided by the after-tax value of one dollar paid out in capital gains, and is sourced from Bartram, Brown, How and Verhoeven (2012) and Fidrmuc and Jacob (2010). Corporate governance measures are from CLSA (2001). \# Firms is the number of firms, and $*, * *$, and $* * *$ denotes significance at the $10 \%, 5 \%$, and $1 \%$ level, respectively. The significance tests $(t$-statistic) test whether the coefficient estimates on the corporate governance variable is statistically different in either different stages of the corporate life-cycle (equation (1)) or in different creditor rights regimes (equation (2)). In both instances, the test-statistic is calculated by estimating either equation (1) or equation (2), and testing the statistical significance of $\beta_{2}$. High RE/TA equals 1 if RE/TA is above the sample median, and zero otherwise. High Creditor equals 1 if creditor rights are greater than 2, and zero otherwise.

$$
\begin{aligned}
& \mathrm{DIV}_{i}=\alpha+\beta_{1} \mathrm{GOV}_{i}+\beta_{2} \mathrm{GOV}_{i} \times \text { High RE} \mathrm{TA}_{i}+\beta_{3} \text { Size }_{i}+\beta_{4} \text { Growth }_{i}+\beta_{5} \text { Profitability }_{i}
\end{aligned}
$$

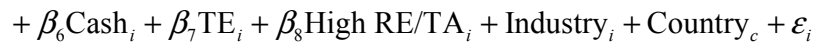

$$
\begin{aligned}
& \operatorname{DIV}_{i}=\alpha+\beta_{1} \mathrm{GOV}_{i}+\beta_{2} \mathrm{GOV}_{i} \times \text { High Creditor }_{i}+\beta_{3} \text { Size }_{i}+\beta_{4} \text { Growth }_{i}+\beta_{5} \text { Profitability }_{i} \\
& +\beta_{6} \mathrm{Cash}_{i}+\beta_{7} \mathrm{TE}_{i}+\beta_{8} \mathrm{RE} / \mathrm{TA}_{i}+\beta_{9} \text { High }_{\text {Creditor }}+\text { Industry }_{i}+\varepsilon_{i}
\end{aligned}
$$

Next, I examine whether my findings are robust to the inclusion of social awareness in the CLSA corporate governance measure. ${ }^{31}$ The results presented in Table 6 suggest that they are. Here again, dividend payout increases in the strength of corporate governance 
(the coefficient estimate on the corporate governance variable is 0.426 and statistically significant $(t$-stat $3.09 ; p<0.01)$, and $0.408(t$-stat is $2.52 ; p<0.05)$ in the weighed least squares regressions). Once again, the outcome model prevails all along the corporate life-cycle (the coefficient estimates on the corporate governance variable is positive and statistically significant for 'mature' and 'immature' firms), but only where shareholder and creditor rights are strong (The coefficient estimate is $0.578(t$-stat is $2.03 ; p<0.05)$ under strong creditor rights and $0.794(t$-stat is $1.94 ; p<0.10)$ under weak creditor rights).

Table 6 Including dividend tax advantage and social awareness in corporate governance measure

\begin{tabular}{|c|c|c|c|c|c|c|c|}
\hline & \multicolumn{7}{|c|}{ Dependent variable is dividends to earnings (\%) } \\
\hline & \multirow[b]{2}{*}{$\begin{array}{c}\text { Full } \\
\text { sample }\end{array}$} & \multicolumn{2}{|c|}{ Life-cycle stage } & \multicolumn{2}{|c|}{$\begin{array}{c}\text { High RE/TA } \\
\text { (Mature) }\end{array}$} & \multicolumn{2}{|c|}{$\begin{array}{l}\text { Low RE/TA } \\
\text { (Immature) }\end{array}$} \\
\hline & & $\begin{array}{l}\text { Low RE/TA } \\
\text { (Immature) }\end{array}$ & $\begin{array}{c}\text { High } \\
\text { RE/TA } \\
\text { (Mature) }\end{array}$ & $\begin{array}{c}H i g h \\
C R\end{array}$ & $\begin{array}{c}\text { Low } \\
C R\end{array}$ & $\begin{array}{c}\text { High } \\
C R\end{array}$ & $\begin{array}{c}\text { Low } \\
\text { CR }\end{array}$ \\
\hline \multicolumn{8}{|c|}{ Ordinary least squares } \\
\hline $\begin{array}{l}\text { Corporate } \\
\text { governance }\end{array}$ & $\begin{array}{c}0.426^{* * *} \\
(3.09)\end{array}$ & $\begin{array}{c}0.538^{* * *} \\
(2.70)\end{array}$ & $\begin{array}{c}0.429 * \\
(1.97)\end{array}$ & $\begin{array}{c}0.578^{* *} \\
(2.03)\end{array}$ & $\begin{array}{c}-0.277 \\
(0.49)\end{array}$ & $\begin{array}{l}0.794 * \\
(1.94)\end{array}$ & $\begin{array}{l}0.116 \\
(0.51)\end{array}$ \\
\hline Size & $\begin{array}{l}1.405 \\
(0.94)\end{array}$ & $\begin{array}{c}4.771^{* *} \\
(2.25)\end{array}$ & $\begin{array}{l}0.049 \\
(0.03)\end{array}$ & $\begin{array}{l}4.171 \\
(1.15)\end{array}$ & $\begin{array}{l}0.867 \\
(0.28)\end{array}$ & $\begin{array}{l}0.433 \\
(0.16)\end{array}$ & $\begin{array}{c}6.082 * * \\
(2.04)\end{array}$ \\
\hline Growth & $\begin{array}{c}-28.580 * * \\
(2.26)\end{array}$ & $\begin{array}{l}11.731 \\
(0.67)\end{array}$ & $\begin{array}{c}-67.306^{* * *} \\
(4.27)\end{array}$ & $\begin{array}{c}-81.756^{* * *} \\
(5.06)\end{array}$ & $\begin{array}{c}-6.662 \\
(0.21)\end{array}$ & $\begin{array}{c}-0.528 \\
(0.04)\end{array}$ & $\begin{array}{c}41.092 * \\
(1.78)\end{array}$ \\
\hline Profitability & $\begin{array}{l}13.977 \\
(0.77)\end{array}$ & $\begin{array}{l}28.295 \\
(1.20)\end{array}$ & $\begin{array}{c}-21.651 \\
(1.00)\end{array}$ & $\begin{array}{c}-33.047 \\
(1.08)\end{array}$ & $\begin{array}{c}-49.343 \\
(1.19)\end{array}$ & $\begin{array}{c}49.538 \\
(1.49)\end{array}$ & $\begin{array}{l}62.598 \\
(1.63)\end{array}$ \\
\hline Cash & $\begin{array}{l}9.045 \\
(0.55)\end{array}$ & $\begin{array}{l}26.424 \\
(1.07)\end{array}$ & $\begin{array}{l}10.253 \\
(0.55)\end{array}$ & $\begin{array}{l}53.380 \\
(1.13)\end{array}$ & $\begin{array}{l}3.957 \\
(0.14)\end{array}$ & $\begin{array}{l}25.662 \\
(0.80)\end{array}$ & $\begin{array}{l}16.832 \\
(0.41)\end{array}$ \\
\hline Total equity & $\begin{array}{l}18.267 \\
(1.35)\end{array}$ & $\begin{array}{c}29.881 * \\
(1.66)\end{array}$ & $\begin{array}{l}3.347 \\
(0.17)\end{array}$ & $\begin{array}{r}-8.863 \\
(0.36)\end{array}$ & $\begin{array}{l}27.960 \\
(0.710\end{array}$ & $\begin{array}{c}-28.933 \\
(1.22)\end{array}$ & $\begin{array}{c}41.796^{*} \\
(1.89)\end{array}$ \\
\hline Retained equity & $\begin{array}{c}13.396^{* *} \\
(2.29)\end{array}$ & $\begin{array}{l}-4.469 \\
(0.90)\end{array}$ & $\begin{array}{l}-2.661 \\
(0.13)\end{array}$ & $\begin{array}{c}-24.125 \\
(0.75)\end{array}$ & $\begin{array}{c}36.657 * * \\
(2.21)\end{array}$ & $\begin{array}{l}4.687 \\
(0.97)\end{array}$ & $\begin{array}{c}-31.484^{* *} \\
(2.10)\end{array}$ \\
\hline $\begin{array}{l}\text { Shareholder } \\
\text { rights }\end{array}$ & $\begin{array}{c}-0.454 \\
(0.20)\end{array}$ & $\begin{array}{c}-1.934 \\
(0.59)\end{array}$ & $\begin{array}{c}-3.239 \\
(0.85)\end{array}$ & $\begin{array}{l}1.326 \\
(0.13)\end{array}$ & $\begin{array}{l}4.936 \\
(0.86)\end{array}$ & $\begin{array}{l}5.804 \\
(0.56)\end{array}$ & $\begin{array}{c}-1.332 \\
(0.31)\end{array}$ \\
\hline Creditor rights & $\begin{array}{l}1.227 \\
(0.53)\end{array}$ & $\begin{array}{l}-4.418 \\
(1.20)\end{array}$ & $\begin{array}{l}5.034 \\
(1.49)\end{array}$ & $\begin{array}{c}27.176^{* *} \\
(2.43)\end{array}$ & $\begin{array}{l}8.568 \\
(0.54)\end{array}$ & $\begin{array}{c}21.400^{*} \\
(1.86)\end{array}$ & $\begin{array}{c}-7.498 \\
(0.64)\end{array}$ \\
\hline $\begin{array}{l}\text { Dividend tax } \\
\text { advantage }\end{array}$ & $\begin{array}{c}23.742 \\
(1.40)\end{array}$ & $\begin{array}{c}-30.303 \\
(1.26)\end{array}$ & $\begin{array}{l}31.611 \\
(1.17)\end{array}$ & $\begin{array}{l}52.684 \\
(0.76)\end{array}$ & $\begin{array}{l}91.166 \\
(1.09)\end{array}$ & $\begin{array}{c}-66.048 \\
(1.44)\end{array}$ & $\begin{array}{c}-76.765 \\
(1.56)\end{array}$ \\
\hline \# Firms & 219 & 109 & 110 & 58 & 52 & 36 & 73 \\
\hline $\begin{array}{l}\text { Country } \\
\text { dummies }\end{array}$ & No & No & No & No & No & No & No \\
\hline $\begin{array}{l}\text { Industry } \\
\text { dummies }\end{array}$ & Yes & Yes & Yes & Yes & Yes & Yes & Yes \\
\hline \multirow[t]{3}{*}{$R$-squared } & 0.315 & 0.470 & 0.368 & 0.629 & 0.401 & 0.879 & 0.470 \\
\hline & & \multicolumn{6}{|c|}{ Tests of significance ( $t$-test) } \\
\hline & & \multicolumn{2}{|c|}{$1.93 *$} & \multicolumn{2}{|c|}{$1.67 *$} & \multicolumn{2}{|c|}{$1.77^{*}$} \\
\hline
\end{tabular}


Table 6 Including dividend tax advantage and social awareness in corporate governance measure (continued)

\begin{tabular}{|c|c|c|c|c|c|c|c|}
\hline & \multicolumn{7}{|c|}{ Dependent variable is dividends to earnings $(\%)$} \\
\hline & \multirow[b]{2}{*}{$\begin{array}{c}\text { Full } \\
\text { sample }\end{array}$} & \multicolumn{2}{|c|}{ Life-cycle stage } & \multicolumn{2}{|c|}{$\begin{array}{l}\text { High RE/TA } \\
\text { (Mature) }\end{array}$} & \multicolumn{2}{|c|}{$\begin{array}{l}\text { Low RE/TA } \\
\text { (Immature) }\end{array}$} \\
\hline & & $\begin{array}{l}\text { Low RE/TA } \\
\text { (Immature) }\end{array}$ & $\begin{array}{c}\text { High } \\
\text { RE/TA } \\
\text { (Mature) }\end{array}$ & $\begin{array}{c}\text { High } \\
C R\end{array}$ & $\begin{array}{c}\text { Low } \\
C R\end{array}$ & $\begin{array}{c}\text { High } \\
\text { CR }\end{array}$ & $\begin{array}{c}\text { Low } \\
C R\end{array}$ \\
\hline \multicolumn{8}{|c|}{ Weighted least squares } \\
\hline $\begin{array}{l}\text { Corporate } \\
\text { governance }\end{array}$ & $\begin{array}{c}0.408 * * \\
(2.52)\end{array}$ & $\begin{array}{c}0.643 * * * \\
(2.80)\end{array}$ & $\begin{array}{c}0.424 * * \\
(1.98)\end{array}$ & $\begin{array}{c}0.612 * * \\
(2.21)\end{array}$ & $\begin{array}{l}0.209 \\
(0.41)\end{array}$ & $\begin{array}{l}0.745 * \\
(1.76)\end{array}$ & $\begin{array}{l}0.212 \\
(0.73)\end{array}$ \\
\hline \# Firms & 219 & 109 & 110 & 58 & 52 & 36 & 73 \\
\hline Controls & Yes & Yes & Yes & Yes & Yes & Yes & Yes \\
\hline $\begin{array}{l}\text { Country } \\
\text { dummies }\end{array}$ & No & No & No & No & No & No & No \\
\hline $\begin{array}{l}\text { Industry } \\
\text { dummies }\end{array}$ & Yes & Yes & Yes & Yes & Yes & Yes & Yes \\
\hline \multirow[t]{3}{*}{$R$-squared } & 0.395 & 0.601 & 0.492 & 0.657 & 0.573 & 0.882 & 0.659 \\
\hline & & \multicolumn{6}{|c|}{ Tests of significance ( $t$-test) } \\
\hline & & \multicolumn{2}{|c|}{1.09} & \multicolumn{2}{|c|}{$2.10 * *$} & \multicolumn{2}{|c|}{$1.82 *$} \\
\hline
\end{tabular}

This table reports coefficient estimates from ordinary and weighted least squares regressions with heteroscedastic consistent $t$-stats presented underneath in parenthesis. The weight of each observation (firm) in the weighted least squares regressions is the inverse of the number of observations (firms) in each country. The sample period is for the year 2001. Separate regressions are estimated for the full sample of firms, for firms with high (above-median, 'mature') and low (below-median, 'immature') retained equity to total assets (RE/TA), and for 'mature' and 'immature' firms in countries with high (above-median i.e., creditor rights measure greater than 2) and low (below-median i.e., creditor rights measure less than and equal to 2 ) creditor rights. The dependent variable is dividends to earnings (\%), dividends to cashflow (\%), and dividends to sales (\%), as indicated. A full set of controls are included, but not reported. All firm-level data is sourced from Worldscope. Dividend Tax Advantage variable measures the after-tax value of one dollar paid out in dividends divided by the after-tax value of one dollar paid out in capital gains, and is sourced from Bartram, Brown, How and Verhoeven (2012) and Fidrmuc and Jacob (2010). Corporate governance measures are from CLSA (2001), and include the social awareness component. \# Firms is the number of firms, and *,**, and $* * *$ denotes significance at the $10 \%, 5 \%$, and $1 \%$ level, respectively. The significance tests ( $t$-statistic) test whether the coefficient estimates on the corporate governance variable is statistically different in either different stages of the corporate life-cycle (equation (1)) or in different creditor rights regimes (equation (2)). In both instances, the test-statistic is calculated by estimating either equation (1) or equation (2), and testing the statistical significance of $\beta_{2}$. High RE/TA equals 1 if RE/TA is above the sample median, and zero otherwise. High Creditor equals 1 if creditor rights are greater than 2 , and zero otherwise.

$$
\begin{aligned}
\mathrm{DIV}_{i}= & \alpha+\beta_{1} \mathrm{GOV}_{i}+\beta_{2} \mathrm{GOV}_{i} \times \text { High RE} \mathrm{TA}_{i}+\beta_{3} \mathrm{Size}_{i}+\beta_{4} \text { Growth }_{i}+\beta_{5} \text { Profitability }_{i} \\
& +\beta_{6} \mathrm{Cash}_{i}+\beta_{7} \mathrm{TE}_{i}+\beta_{8} \text { High RE} / \mathrm{TA}_{i}+\text { Industry }_{i}+\text { Country }_{c}+\varepsilon_{i} \\
\mathrm{DIV}_{i}= & \alpha+\beta_{1} \mathrm{GOV}_{i}+\beta_{2} \mathrm{GOV}_{i} \times \text { High Creditor }_{i}+\beta_{3} \text { Size }_{i}+\beta_{4} \text { Growth }_{i}+\beta_{5} \text { Profitability }_{i} \\
& +\beta_{6} \mathrm{Cash}_{i}+\beta_{7} \mathrm{TE}_{i}+\beta_{8} \mathrm{RE} \mathrm{TA}_{i}+\beta_{9} \text { High Creditor }_{i}+\text { Industry }_{i}+\varepsilon_{i}
\end{aligned}
$$


In Table 7, I examine whether these same findings are robust to the use of an alternative proxy for the firm life-cycle. My choice of alternative proxy is motivated by recent work, which shows that corporate cash holdings decrease monotonically over the corporate life-cycle (Dittmar and Duchin, 2011), because, amongst others, the firm's investment opportunity set diminishes, and presumably the need for cash diminishes (Ferreira and Vilela, 2004). With this in mind, I classify 'mature' ('immature') firms as those with cash holdings (scaled by book assets) above (below) the sample median ratio of cash to book assets, respectively. Once again, I find that the outcome model prevails all along the corporate life-cycle, but only where creditors (and shareholders) are well protected. For example, for 'immature' firms the coefficient estimate on the corporate governance variable is $0.626(t$-stat is $1.69 ; p<0.10)$ under strong creditor rights and -0.369 ( $t$-stat is 1.39) given weak creditor rights.

In Table 8, I try to address concerns regarding sample selection bias. My sample is small because on the one hand, the number of firms followed by the CLSA is small, and of these firms, the retained equity variable (RE/TA and RE/TE) is only available for 220 firms. My ability to alleviate concerns surrounding sample selection bias is limited, because I cannot include developed market firms and create a much larger sample size because of lack of data availability. What I can do is increase my sample size by using an alternative corporate life-cycle measure e.g., corporate cash holding, which is available for more than the 220 firms in my original sample. When I use corporate cash holdings to proxy for the corporate life-cycle, the sample of firm's increases from 220 to 281 firms (see Column labelled '\# Firm 2' in Table 1). The additional firms come from India (48 firms compared to just 13 before), and Singapore ( 26 firms compared to 18 before). ${ }^{32}$ The results presented in Table 8 suggest that my earlier findings do extend to a larger sample of emerging market firms. Dividend payout is an outcome of effective governance, at all stages of the corporate life-cycle, but only where shareholder and creditor rights are strong.

Table 7 Using cash holdings to proxy for stage of corporate life-cycle

\begin{tabular}{|c|c|c|c|c|c|c|c|}
\hline & \multicolumn{7}{|c|}{ Dependent variable is dividends to earnings (\%) } \\
\hline & \multirow[b]{2}{*}{$\begin{array}{c}\text { Full } \\
\text { sample }\end{array}$} & \multicolumn{2}{|c|}{ Life-cycle stage } & \multicolumn{2}{|c|}{$\begin{array}{c}\text { High cash/TA } \\
\text { (Immature) }\end{array}$} & \multicolumn{2}{|c|}{$\begin{array}{c}\text { Low cash/TA } \\
\text { (Mature) }\end{array}$} \\
\hline & & $\begin{array}{c}\text { Low } \\
\text { cash } / T A \\
\text { (Mature) }\end{array}$ & $\begin{array}{c}\text { High } \\
\text { cash/TA } \\
\text { (Immature) }\end{array}$ & $\begin{array}{c}\text { High } \\
\text { CR }\end{array}$ & $\begin{array}{l}\text { Low } \\
C R\end{array}$ & $\begin{array}{l}\text { High } \\
\text { CR }\end{array}$ & $\begin{array}{l}\text { Low } \\
\text { CR }\end{array}$ \\
\hline \multicolumn{8}{|c|}{ Ordinary least squares } \\
\hline $\begin{array}{l}\text { Corporate } \\
\text { governance }\end{array}$ & $\begin{array}{c}0.426^{* * *} \\
(3.09)\end{array}$ & $\begin{array}{c}0.502 * * \\
(2.17)\end{array}$ & $\begin{array}{l}0.194 \\
(1.02)\end{array}$ & $\begin{array}{c}0.626^{*} \\
(1.69)\end{array}$ & $\begin{array}{l}-0.369 \\
(1.39)\end{array}$ & $\begin{array}{c}0.491 * * \\
(2.05)\end{array}$ & $\begin{array}{l}-0.458 \\
(0.50)\end{array}$ \\
\hline \# Firms & 219 & 109 & 110 & 51 & 59 & 43 & 66 \\
\hline Controls & Yes & Yes & Yes & Yes & Yes & Yes & Yes \\
\hline $\begin{array}{l}\text { Country } \\
\text { dummies }\end{array}$ & No & No & No & No & No & No & No \\
\hline $\begin{array}{l}\text { Industry } \\
\text { dummies }\end{array}$ & Yes & Yes & Yes & Yes & Yes & Yes & Yes \\
\hline \multirow[t]{3}{*}{$R$-squared } & 0.315 & 0.331 & 0.459 & 0.548 & 0.707 & 0.311 & 0.491 \\
\hline & & \multicolumn{6}{|c|}{ Tests of significance ( $t$-test) } \\
\hline & & \multicolumn{2}{|c|}{$2.08 * * *$} & \multicolumn{2}{|c|}{$2.32 * * *$} & \multicolumn{2}{|c|}{$2.65 * * *$} \\
\hline
\end{tabular}


Table 7 Using cash holdings to proxy for stage of corporate life-cycle (continued)

\begin{tabular}{|c|c|c|c|c|c|c|c|}
\hline & \multicolumn{7}{|c|}{ Dependent variable is dividends to earnings (\%) } \\
\hline & \multirow[b]{2}{*}{$\begin{array}{c}\text { Full } \\
\text { sample }\end{array}$} & \multicolumn{2}{|c|}{ Life-cycle stage } & \multicolumn{2}{|c|}{$\begin{array}{l}\text { High cash/TA } \\
\text { (Immature) }\end{array}$} & \multicolumn{2}{|c|}{$\begin{array}{l}\text { Low cash/TA } \\
\text { (Mature) }\end{array}$} \\
\hline & & $\begin{array}{c}\text { Low } \\
\text { cash/TA } \\
\text { (Mature) }\end{array}$ & $\begin{array}{c}\text { High } \\
\text { cash/TA } \\
\text { (Immature) }\end{array}$ & $\begin{array}{c}\text { High } \\
\text { CR }\end{array}$ & $\begin{array}{l}\text { Low } \\
\text { CR }\end{array}$ & $\begin{array}{l}\text { High } \\
C R\end{array}$ & $\begin{array}{l}\text { Low } \\
\text { CR }\end{array}$ \\
\hline \multicolumn{8}{|c|}{ Weighted least squares } \\
\hline $\begin{array}{l}\text { Corporate } \\
\text { governance }\end{array}$ & $\begin{array}{c}0.408 * * \\
(2.52)\end{array}$ & $\begin{array}{l}0.450^{*} \\
(1.93)\end{array}$ & $\begin{array}{l}0.047 \\
(0.24)\end{array}$ & $\begin{array}{l}0.621^{*} \\
(1.72)\end{array}$ & $\begin{array}{l}-0.294 \\
(1.12)\end{array}$ & $\begin{array}{c}0.537 * * \\
(2.30)\end{array}$ & $\begin{array}{l}0.005 \\
(0.01)\end{array}$ \\
\hline \# Firms & 219 & 109 & 110 & 51 & 59 & 43 & 66 \\
\hline Controls & Yes & Yes & Yes & Yes & Yes & Yes & Yes \\
\hline $\begin{array}{l}\text { Country } \\
\text { dummies }\end{array}$ & No & No & No & No & No & No & No \\
\hline $\begin{array}{l}\text { Industry } \\
\text { dummies }\end{array}$ & Yes & Yes & Yes & Yes & Yes & Yes & Yes \\
\hline \multirow[t]{3}{*}{$R$-squared } & 0.395 & 0.569 & 0.542 & 0.583 & 0.759 & 0.341 & 0.508 \\
\hline & & \multicolumn{6}{|c|}{ Tests of significance ( $t$-test) } \\
\hline & & \multicolumn{2}{|c|}{$2.14 * * *$} & \multicolumn{2}{|c|}{$2.44 * * *$} & \multicolumn{2}{|c|}{$2.56 * * *$} \\
\hline
\end{tabular}

This table reports coefficient estimates from ordinary and weighted least squares regressions with heteroscedastic consistent $t$-stats presented underneath in parenthesis. The weight of each observation (firm) in the weighted least squares regressions is the inverse of the number of observations (firms) in each country. The sample period is for the year 2001. Separate regressions are estimated for the full sample of firms, for firms with high (above-median, 'immature') and low (below-median, 'immature') cash to total assets (Cash/TA), and for 'mature' and 'immature' firms in countries with high (above-median i.e., creditor rights measure greater than 2) and low (below-median i.e., creditor rights measure less than and equal to 2 ) creditor rights. The dependent variable is dividends to earnings (\%), dividends to cashflow (\%), and dividends to sales (\%), as indicated. A full set of controls are included, but not reported. All firm-level data is sourced from Worldscope. Corporate governance measures are from CLSA (2001). \# Firms is the number of firms, and ***, and *** denotes significance at the $10 \%, 5 \%$, and $1 \%$ level, respectively. The significance tests ( $t$-statistic) test whether the coefficient estimates on the corporate governance variable is statistically different in either different stages of the corporate life-cycle (equation (1)) or in different creditor rights regimes (equation (2)). In both instances, the test-statistic is calculated by estimating either equation (1) or equation (2), and testing the statistical significance of $\beta_{2}$. Low Cash/TA equals 1 if Cash/TA is below the sample median, and zero otherwise. High Creditor equals 1 if creditor rights are greater than 2 , and zero otherwise.

$$
\begin{aligned}
& \mathrm{DIV}_{i}=\alpha+\beta_{1} \mathrm{GOV}_{i}+\beta_{2} \mathrm{GOV}_{i} \times \text { Low Cash } \mathrm{TA}_{i}+\beta_{3} \mathrm{Size}_{i}+\beta_{4} \text { Growth }_{i}+\beta_{5} \text { Profitability }_{i} \\
& +\beta_{6} \text { Low Cash } / \mathrm{TA}_{i}+\beta_{7} \mathrm{TE}_{i}+\beta_{8} \mathrm{RE} \mathrm{TA}_{i}+\text { Industry }_{i}+\text { Country }_{c}+\varepsilon_{i} \\
& \operatorname{DIV}_{i}=\alpha+\beta_{1} \mathrm{GOV}_{i}+\beta_{2} \mathrm{GOV}_{i} \times \text { High Creditor }_{i}+\beta_{3} \text { Size }_{i}+\beta_{4} \text { Growth }_{i}+\beta_{5} \text { Profitability }_{i} \\
& +\beta_{6} \mathrm{Cash} / \mathrm{TA}_{i}+\beta_{7} \mathrm{TE}_{i}+\beta_{8} \mathrm{RE} / \mathrm{TA}_{i}+\beta_{9} \text { High Creditor }_{i}+\text { Industry }_{i}+\varepsilon_{i}
\end{aligned}
$$




\section{Conclusions}

In this paper, I test the outcome and substitution models of dividends of La Porta et al. (2000) along the corporate life-cycle. I present two hypotheses. The first (and second) state that the outcome (substitution) model of dividends is most likely to prevail when firms are 'mature' ('immature'). To the best of my knowledge, I am the first to test these two hypotheses using a sample of emerging market firms. Using a sample of 220 firms from 21 emerging markets, I find no evidence to suggest that the substitution model prevails in emerging markets. In contrast, the outcome model holds at early and later stages along the corporate life-cycle. While, as expected, dividend payouts are much lower when firms are 'immature' i.e., have negative or low ratios of retained equity to assets (or total equity), compared to when firms are 'mature', and at all stages along the corporate life-cycle, better-governed firms pay larger dividends than their poorly-governed counterparts. However, on closer inspection, I find that they can only do so provided creditor rights are strong. Where creditor rights are weak, shareholders of better-governed firms appear powerless to prevent firms from consenting to the demands from creditors for lower dividends. These findings are in line with those of Brockman and Unlu (2009), Shao et al. (2009), Byrne and O'Connor (2012). They show that the agency cost of equity and debt version of the outcome model of dividends holds i.e., dividend payouts are largest where shareholder and creditor rights are strong. These findings also suggest that poorly-governed firms do not substitute poor governance with higher dividends, as the substitution model would predict. Hence, these poorly-governed firms either do not view dividends as a bonding mechanism, or alternatively, they may use alternative bonding devices e.g., cross-list internationally to reduce the agency costs of poor governance.

Table 8 Using cash holdings as a proxy for corporate life-cycle and a larger sample size

\begin{tabular}{|c|c|c|c|c|c|c|c|}
\hline & \multicolumn{7}{|c|}{ Dependent variable is dividends to earnings (\%) } \\
\hline & \multirow[b]{2}{*}{$\begin{array}{c}\text { Full } \\
\text { sample }\end{array}$} & \multicolumn{2}{|c|}{ Life-cycle stage } & \multicolumn{2}{|c|}{$\begin{array}{c}\text { High cash/TA } \\
\text { (Immature) }\end{array}$} & \multicolumn{2}{|c|}{$\begin{array}{l}\text { Low cash/TA } \\
\text { (Mature) }\end{array}$} \\
\hline & & $\begin{array}{c}\text { Low } \\
\text { cash/TA } \\
\text { (Mature) }\end{array}$ & $\begin{array}{c}\text { High } \\
\text { cash/TA } \\
\text { (Immature) }\end{array}$ & $\begin{array}{l}\text { High } \\
C R\end{array}$ & $\begin{array}{l}\text { Low } \\
C R\end{array}$ & $\begin{array}{l}\text { High } \\
C R\end{array}$ & $\begin{array}{c}\text { Low } \\
C R\end{array}$ \\
\hline \multicolumn{8}{|c|}{ Ordinary least squares } \\
\hline $\begin{array}{l}\text { Corporate } \\
\text { governance }\end{array}$ & $\begin{array}{c}0.242 * \\
(1.67)\end{array}$ & $\begin{array}{c}0.525 * * * \\
(2.83)\end{array}$ & $\begin{array}{c}0.278^{*} \\
(1.69)\end{array}$ & $\begin{array}{c}0.654 * \\
(1.72)\end{array}$ & $\begin{array}{c}-0.176 \\
(0.82)\end{array}$ & $\begin{array}{c}0.580 * * * \\
(2.91)\end{array}$ & $\begin{array}{l}-0.229 \\
(0.20)\end{array}$ \\
\hline \# Firms & 281 & 141 & 140 & 55 & 85 & 38 & 103 \\
\hline Controls & Yes & Yes & Yes & Yes & Yes & Yes & Yes \\
\hline $\begin{array}{l}\text { Country } \\
\text { dummies }\end{array}$ & No & No & No & No & No & No & No \\
\hline $\begin{array}{l}\text { Industry } \\
\text { dummies }\end{array}$ & Yes & Yes & Yes & Yes & Yes & Yes & Yes \\
\hline \multirow[t]{3}{*}{$R$-squared } & 0.325 & 0.202 & 0.314 & 0.400 & 0.366 & 0.258 & 0.301 \\
\hline & & \multicolumn{6}{|c|}{ Tests of significance ( $t$-test) } \\
\hline & & \multicolumn{2}{|c|}{$1.81 *$} & \multicolumn{2}{|c|}{$2.41 * * *$} & \multicolumn{2}{|c|}{$2.52 * * *$} \\
\hline
\end{tabular}


Table 8 Using cash holdings as a proxy for corporate life-cycle and a larger sample size (continued)

\begin{tabular}{|c|c|c|c|c|c|c|c|}
\hline & \multicolumn{7}{|c|}{ Dependent variable is dividends to earnings (\%) } \\
\hline & \multirow[b]{2}{*}{$\begin{array}{c}\text { Full } \\
\text { sample }\end{array}$} & \multicolumn{2}{|c|}{ Life-cycle stage } & \multicolumn{2}{|c|}{$\begin{array}{c}\text { High cash/TA } \\
\text { (Immature) }\end{array}$} & \multicolumn{2}{|c|}{$\begin{array}{l}\text { Low cash/TA } \\
\text { (Mature) }\end{array}$} \\
\hline & & $\begin{array}{c}\text { Low } \\
\text { cash } / T A \\
\text { (Mature) }\end{array}$ & $\begin{array}{c}\text { High } \\
\text { cash/TA } \\
\text { (Immature) }\end{array}$ & $\begin{array}{l}\text { High } \\
C R\end{array}$ & $\begin{array}{c}\text { Low } \\
C R\end{array}$ & $\begin{array}{c}\text { High } \\
\text { CR }\end{array}$ & $\begin{array}{l}\text { Low } \\
\text { CR }\end{array}$ \\
\hline \multicolumn{8}{|c|}{ Weighted least squares } \\
\hline $\begin{array}{l}\text { Corporate } \\
\text { governance }\end{array}$ & $\begin{array}{c}0.235^{*} \\
(1.70)\end{array}$ & $\begin{array}{c}0.495 * * \\
(2.46)\end{array}$ & $\begin{array}{l}0.228 \\
(1.36)\end{array}$ & $\begin{array}{c}0.643^{*} \\
(1.69)\end{array}$ & $\begin{array}{c}-0.186 \\
(0.80)\end{array}$ & $\begin{array}{c}0.619 * * * \\
(3.14)\end{array}$ & $\begin{array}{c}-0.114 \\
(0.18)\end{array}$ \\
\hline \# Firms & 281 & 141 & 140 & 55 & 85 & 38 & 103 \\
\hline Controls & Yes & Yes & Yes & Yes & Yes & Yes & Yes \\
\hline $\begin{array}{l}\text { Country } \\
\text { dummies }\end{array}$ & No & No & No & No & No & No & No \\
\hline $\begin{array}{l}\text { Industry } \\
\text { dummies }\end{array}$ & Yes & Yes & Yes & Yes & Yes & Yes & Yes \\
\hline \multirow[t]{3}{*}{$R$-squared } & 0.568 & 0.501 & 0.304 & 0.423 & 0.392 & 0.286 & 0.456 \\
\hline & & \multicolumn{6}{|c|}{ Tests of significance ( $t$-test) } \\
\hline & & \multicolumn{2}{|c|}{$1.91 *$} & \multicolumn{2}{|c|}{$2.45 * * *$} & \multicolumn{2}{|c|}{$2.61 * * *$} \\
\hline
\end{tabular}

This table reports coefficient estimates from ordinary and weighted least squares regressions with heteroscedastic consistent $t$-stats presented underneath in parenthesis. The weight of each observation (firm) in the weighted least squares regressions is the inverse of the number of observations (firms) in each country. The sample period is for the year 2001, and the sample is extended to 281 firms in total. Separate regressions are estimated for the full sample of firms, for firms with high (above-median, 'immature') and low (below-median, 'immature') cash to total assets (Cash/TA), and for 'mature' and 'immature' firms in countries with high (above-median i.e., creditor rights measure greater than 2) and low (below-median i.e., creditor rights measure less than and equal to 2 ) creditor rights. The dependent variable is dividends to earnings (\%), dividends to cashflow (\%), and dividends to sales (\%), as indicated. A full set of controls are included, but not reported. All firm-level data is sourced from Worldscope. Corporate governance measures are from CLSA (2001). \# Firms is the number of firms, and *,**, and *** denotes significance at the $10 \%, 5 \%$, and $1 \%$ level, respectively. The significance tests ( $t$-statistic) test whether the coefficient estimates on the corporate governance variable is statistically different in either different stages of the corporate life-cycle (equation (1)) or in different creditor rights regimes (equation (2)). In both instances, the test-statistic is calculated by estimating either equation (1) or equation (2), and testing the statistical significance of $\beta_{2}$. Low Cash/TA equals 1 if Cash/TA is below the sample median, and zero otherwise. High Creditor equals 1 if creditor rights are greater than 2, and zero otherwise.

$$
\begin{aligned}
& \mathrm{DIV}_{i}=\alpha+\beta_{1} \mathrm{GOV}_{i}+\beta_{2} \mathrm{GOV}_{i} \times \text { Low Cash } / \mathrm{TA}_{i}+\beta_{3} \text { Size }_{i}+\beta_{4} \text { Growth }_{i}+\beta_{5} \text { Profitability }_{i} \\
& +\beta_{6} \text { Low Cash } / \mathrm{TA}_{i}+\beta_{7} \mathrm{TE}_{i}+\beta_{8} \mathrm{RE} \mathrm{TA}_{i}+\text { Industry }_{i}+\text { Country }_{c}+\varepsilon_{i} \\
& \mathrm{DIV}_{i}=\alpha+\beta_{1} \mathrm{GOV}_{i}+\beta_{2} \mathrm{GOV}_{i} \times \text { High Creditor }_{i}+\beta_{3} \text { Size }_{i}+\beta_{4} \text { Growth }_{i}+\beta_{5} \text { Profitability }_{i} \\
& +\beta_{6} \mathrm{Cash} / \mathrm{TA}_{i}+\beta_{7} \mathrm{TE}_{i}+\beta_{8} \mathrm{RE} / \mathrm{TA}_{i}+\beta_{9} \text { High Creditor }_{i}+\text { Industry }_{i}+\varepsilon_{i}
\end{aligned}
$$




\section{References}

Adjaoud, F. and Ben-Amar, W. (2010) 'Corporate governance and dividend policy: shareholders' protection or expropriation?', Journal of Business, Finance, \& Accounting, Vol. 37, pp.648-667.

Aggarwal, R., Erel, I., Stulz, R. and Williamson, R. (2009) 'Differences in governance practices between U.S. and foreign firms: measurement, causes, and consequences', Review of Financial Studies, Vol. 22, pp.3131-3169.

Bartram, S., Brown, P., How, J. and Verhoeven, P. (2012) Agency Conflicts and Corporate Payout Policies: A Global Study, Working paper, Lancaster University, UK.

Benos, B. and Weisbach, M. (2004) 'Private benefits and cross-listings in the United States', Emerging Markets Review, Vol. 5, pp.217-240.

Bhattacharya, S. (1979) 'Imperfect information, dividend policy, and the 'bird in the hand' fallacy', Bell Journal of Economics, Vol. 10, pp.259-270.

Black, B., de Carvalho, A. and Gorga, E. (2012) 'What matters and for which firms for corporate governance in emerging markets? Evidence from Brazil (and other BRIK countries)', Journal of Corporate Finance, Vol. 18, pp.934-952.

Brockman, P. and Unlu, E. (2009) 'Dividend policy, creditor rights, and the agency costs of debt', Journal of Financial Economics, Vol. 92, pp.276-299.

Brockman, P. and Unlu, E. (2011) 'Earned/contributed capital, dividend policy, and disclosure quality: an international study', Journal of Banking \& Finance, Vol. 35, pp.1610-1625.

Bulan, L. and Subramanian, N. (2009) 'The firm life cycle theory of dividends', in Kent Baker, H. (Ed.): Dividends and Dividend Policy, Wiley, New Jersey, pp.201-213.

Bulan, L., Subramanian, N. and Tanlu, L. (2007) 'On the timing of dividend initiations', Financial Management, Vol. 36, pp.31-65.

Byrne, J. and O'Connor, T. (2012) 'Creditor rights and the outcome model of dividends', The Quarterly Review of Economics and Finance, Vol. 52, pp.227-242.

Chae, J., Kim, S. and Lee, E. (2009) 'How corporate governance affects payout policy under agency problems and external financing constraints', Journal of Banking and Finance, Vol. 33, pp.2093-2101.

Chen, K., Chen, Z. and Wei, K. (2009) 'Legal protection of investors, corporate governance, and the cost of equity capital', Journal of Corporate Finance, Vol. 15, pp.273-289.

Credit Lyonnais Securities Asia (CLSA) (2001) Saints and Sinners: Who's Got Religion?, Published Report.

DeAngelo, H., DeAngelo, L. and Stulz, R. (2006) 'Dividend policy and the earned/ contributed capital mix: a test of the life-cycle theory', Journal of Financial Economics, Vol. 81, pp.227-254.

Denis, D. and Osobov, I. (2008) 'Why do firms pay dividends? International evidence on the determinants of dividend policy', Journal of Financial Economics, Vol. 89, pp.62-82.

Dittmar, A. and Duchin, R. (2011) The Dynamics of Cash, Working Paper, University of Michigan, USA.

Djankov, S., La Porta, R., Lopez-de-Silanes, F. and Shleifer, A. (2008) 'The law and economics of self-dealing', Journal of Financial Economics, Vol. 88, pp.430-465.

Djankov, S., McLeish, C. and Shleifer, A. (2007) 'Private credit in 129 countries', Journal of Financial Economics, Vol. 84, pp.299-329.

Doidge, C., Karolyi, G.A. and Stulz, R. (2007) 'Why do countries matter so much for corporate governance?', Journal of Financial Economics, Vol. 86, pp.1-39.

Durnev, A. and Kim, E. (2005) 'To steal or not to steal: firm attributes, legal environment, and valuation', Journal of Finance, pp.1461-1493. 
Durnev, A. and Kim, E. (2007) 'Explaining differences in the quality of governance among companies: evidence from emerging markets', Journal of Applied Corporate Finance, Vol. 19, pp.16-24.

Easterbrook, F. (1984) 'Two agency cost explanations of dividends', American Economic Review, Vol. 74, pp.650-659.

Faccio, M., Lang, L. and Young, L. (2001) 'Dividends and expropriation', The American Economic Review, Vol. 91, pp.54-78.

Ferreira, M. and Vilela, A. (2004) 'Why do firms hold cash? Evidence from EMU countries', European Financial Management, Vol. 10, pp.295-319.

Fidrmuc, J. and Jacob, M. (2010) 'Culture, agency costs, and dividends', Journal of Comparative Economics, Vol. 38, pp.321-339.

Francis, B., Hasan, I., John, K. and Song, L. (2011) 'Corporate governance and dividend payout policy: a test using anti-takeover legislation', Financial Management, Vol. 40, pp.83-112.

Gompers, P., Ishii, J. and Metrick, A. (2003) 'Corporate governance and equity prices', The Quarterly Journal of Economics, Vol. 118, pp.107-155.

Grullon, G., Michaely, R. and Swaminathan, B. (2002) 'Are dividend changes a sign of firm maturity?', Journal of Business, Vol. 75, pp.387-424.

Jensen, M. (1986) 'Agency costs of free cash flow, corporate finance and takeovers', American Economic Review, Vol. 76, pp.323-339.

Jiraporn, P. and Ning, Y. (2006) 'Dividend policy, shareholder rights, and corporate governance', Journal of Applied Finance, Vol. 16, pp.24-36.

Jiraporn, P., Kim, Y. and Kim, J. (2011) 'Dividend policy and corporate governance quality: evidence from ISS', The Financial Review, Vol. 46, pp.251-279.

Jo, H. and Pan, C. (2009) 'Why are firms with entrenched managers more likely to pay dividends?', Review of Accounting and Finance, Vol. 8, pp.87-116.

John, K. and Knyazeva, A. (2006) Payout Policy, Agency Conflicts, and Corporate Governance, Working Paper, New York University, USA.

Kalay, A. (1982) 'Stockholder-bondholder conflict and dividend constraint', Journal of Financial Economics, Vol. 14, pp.423-449.

Klapper, L. and Love, I. (2004) 'Corporate governance, investor protection and performance in emerging markets', Journal of Corporate Finance, Vol. 10, pp.703-728.

La Porta, R., Lopez-de-Silanes, F., Shleifer, A. and Vishny, R. (2000) 'Agency problems and dividend policy around the world', Journal of Finance, Vol. 55, pp.1-33.

La Porta, R., Lopez-de-Silanes, F., Shleifer, A. and Vishny, R. (1998) 'Law and finance', Journal of Political Economy, Vol. 106, pp.1113-1155.

Liu, W. (2002) Do Dividends Substitute for the External Corporate Governance? A Cross-country Dynamic View, Working Paper, Indiana University, USA.

Mansi, S. and Wald, J. (2011) 'Payout policy with legal restrictions', Financial Management, Vol. 40, pp.701-732.

Mitton, T. (2004) 'Corporate governance and dividend policy in emerging markets', Emerging Markets Review, Vol. 5, pp.409-426.

O'Connor, T. (2006) 'Cross-listing in the U.S. and domestic investor protection', The Quarterly Review of Economics and Finance, Vol. 46, pp.413-436.

Officer, M.S. (2011) 'Overinvestment, corporate governance, and dividend initiations, and governance', Journal of Corporate Finance, Vol. 17, pp.710-724.

Petrasek, L. (2012) 'Do transparent firms payout more cash to shareholders? Evidence from international cross-listings', Financial Management, Vol. 41, pp.615-636.

Rommens, A., Cuyvers, L. and Deloof, M. (2012) 'Dividend policies of privately held companies: stand-alone and group companies in Belgium', European Financial Management, Vol. 18, pp.816-835. 
Ross, S. (1977) 'The determination of financial structure: the incentive-signaling approach', Bell Journal of Economics, Vol. 1, pp.23-40.

Sawicki, J. (2009) 'Corporate governance and dividend policy in Southeast Asia pre- and post-crisis', European Journal of Finance, Vol. 15, pp.211-230.

Shao, L., Kwok, C. and Guedhami, O. (2009) Dividend Policy: Balancing Interests between Shareholders and Creditors, Working Paper, University of South California, USA.

Smith, C. and Warner, J. (1979) 'On financial contracting: an analysis of bond covenants', Journal of Financial Economics, Vol. 7, pp.117-161.

Spamann, H. (2010) 'The 'antidirector rights index' revisited', Review of Financial Studies, Vol. 23, pp.467-486.

White, H. (1980) 'A heteroscedasticity-consistent covariance matrix estimator and a direct test for heteroscedasticity', Econometrica, Vol. 48, pp.817-838.

\section{Notes}

${ }^{1}$ The signalling models of dividends suggest that dividend initiations lead and not lag (as the life-cycle model of dividends predicts) firm profitability (see for example Ross, 1977; Bhattacharya, 1979).

${ }^{2}$ For a review of the life-cycle model of dividends, see Bulan and Subramanian (2009).

${ }^{3}$ In continental Europe and Asia, the 'principal-agent' problem is best characterized as a conflict between a principal and a principal, namely the controlling and minority shareholders, as opposed to managers and shareholders. Faccio et al. (2001) show that the risk of expropriation of minority insiders in family/closely held European firms is reduced because of sizable dividend payouts. For similar firms in Asia, dividend payouts tend to be much lower.

${ }^{4}$ Using a sample of US firms, Chae et al. (2009) show that dividend payout increases in both corporate governance and the amount of free cash flow. However, in the absence of free cash flow, dividend payout actually decreases in the strength of corporate governance i.e., the substitution model prevails.

${ }^{5}$ Some papers focus solely on the relationship between the strength of corporate governance and the dividend amount (see Mitton, 2004; Sawicki, 2009; Chae et al., 2009). Others establish the relationship between the strength of corporate governance and the likelihood of paying a dividend and the dividend amount (see Byrne and O'Connor, 2012; Bartram et al., 2012). Brockman and Unlu (2009, 2011), Byrne and O'Connor (2012), and Shao et al. (2009) all focus on the relationship between country measures of shareholder (and creditor) rights and the likelihood of paying a dividend and the dividend amount.

${ }^{6}$ Debt also serves to reduce the agency costs of free cash flow. Mansi and Wald (2011) show that where firms face limitations on the use of debt, they pay larger dividends to reduce the free cash flow problem.

${ }^{7}$ The results of these tests using US firms are mixed. Using the anti-takeover governance index of Gompers et al. (2003) to measure the strength of corporate governance of US firms, John and Knyazeva (2006), Officer (2011), Jo and Pan (2009), Jiraporn and Ning (2006) find in favour of the substitution model. Again using US firms, but now using governance data from the Institutional Shareholder Services, Jiraporn et al. (2011) find evidence in favour of the outcome model. The ISS data is a much broader corporate governance measure than the G-Index, which in turn, likely explains the conflicting findings.

${ }^{8}$ Ideally, I would have liked to have used a sample of developed and emerging market firms in this paper. I focus solely on emerging market firms since I do not have access to corporate governance data for developed market firms, and only have access to corporate governance data for emerging market firms for the year 2001.

${ }^{9}$ Others do concentrate on the agency models of total payout. These include Bartram et al. (2012), Mansi and Wald (2011), and Petrasek (2012). I focus solely on dividend payouts because I do not have access to share repurchase data. 
${ }^{10}$ Like Mitton (2004) and La Porta et al. (2000) I assume that past growth rates proxy for future growth opportunities. Hence, I do not use the market-to-book ratio as a measure of a firm's future growth opportunities.

${ }^{11}$ The dividend polices of publicly traded and private firms tend to be different. Rommens et al. (2012) compare the dividend policies of public and privately held firms in Belgium. They show that privately held firms typically do not pay a dividend, and for those that do, the dividend payout is less than that of publicly-traded firms.

${ }^{12} \mathrm{~A}$ large literature exists which examines the firm and country-level factors which promote firms to practice better corporate governance (see for example, Klapper and Love, 2004; Durnev and Kim, 2005, 2007). These 'governance-predictions' studies find that amongst others, large firms, firms with a need for external finance, and firms with large proportion of 'soft/intangible' assets practice good corporate governance. They also find that corporate governance improves with ownership concentration, provided there is no deviation from one-share-one-vote (i.e., dual-class firms typically have poorer governance than single-class share firms). Cross-listing firms and firms domiciled where country governance (e.g., shareholder rights strong, efficient judiciary) is strong also tend to be better governed. However, Doidge et al. (2007) show that some firms with these 'desirable' characteristics may not necessarily practice better governance, since the costs of doing so can outweigh the perceived benefits. The costs of doing so are greater where financial development weak. Aggarwal et al. (2009) highlight the differences in governance practices between US and non-US firms, and show that amongst others, differences in financial development between the US and non-US countries can explain part of the superior governance practices of US firms. Furthermore, recent work suggests that some firms do not adopt 'desirable' aspects of corporate governance since their adoption can prove to be value-decreasing (Black et al., 2012).

${ }^{13}$ Klapper and Love (2004) show that the variation in corporate governance ratings (using CLSA corporate governance scores) decreases as country level investor protection increases.

${ }^{14}$ The best and worst governed firms in the sample have governance scores of 92.77 and 11.77 , respectively (Range is 81). The interquartile range is 21.56 .

${ }^{15}$ The maximum (and range since the minimum dividend payout is zero) dividends to earnings, cashflow, and sales is $85.5,82.2$, and $21.0 \%$, respectively.

${ }^{16}$ Firms are designated into one of 13 industries based on the following classifications using 4-digit SIC codes: Agriculture and Food (0100-0999 \& 2000-2111); Mining and Construction (1000-1999, excluding 1300-1399); Textiles and Printing/Publishing (2200-2799); Chemicals (2800-2824, 2840-2899); Pharmaceuticals (2830-2836); Extractive (2900-2999, 1300-1399); Durable Manufacturers (3000-3999, excluding 3570-3579); Transportation (4000-4899); Utilities (4900-4999); Retail (5000-5999); Services (7000-8999, excluding 7370-7379); Computers (7370-7379, 3570-3579, 3670-3679); Public Administration (9000+).

${ }^{17}$ Mitton (2004) estimates variants of equations 1 and 2 . His version of equation 1 excludes cash, total equity and retained equity, and excludes these same variables and creditor rights from equation 2. Using both dividends to cashflow (\%) and dividends to sales (\%), the coefficient estimates on the corporate governance variable is comparable across studies. For example, using equation 1, the coefficient estimates on the corporate governance variable reported by Mitton (2004) is 0.278 and 0.056 (Using dividends to cashflow (\%) and dividends to sales (\%)), respectively. I report coefficient estimates of 0.270 and 0.070 , respectively. Using dividends to earnings $(\%)$, the coefficient estimates on the corporate governance variable are much larger in this study (0.369) compared to 0.271 in Mitton (2004).

${ }^{18}$ The conclusions are qualitatively unaffected when I use RE/TE in place of RE/TA.

${ }^{19}$ Bartram et al. (2012) do find support for the outcome model when they use Spamann's (2010) anti-director rights measure.

${ }^{20} \mathrm{My}$ results remain qualitatively unchanged when I exclude countries with a single observation (firm) i.e., Argentina, Colombia, Peru, and Poland. 
${ }^{21}$ For brevity sake, I only present the results using retained equity to total assets. The conclusions remain qualitatively unchanged when I use the ratio of retained equity to total equity to proxy for the corporate life-cycle. These results are presented in an earlier working paper version of this paper, and are also available from me upon request.

${ }^{22}$ The significance tests ( $t$-statistic) reported in Table 3 test whether the coefficient estimates on the corporate governance variable is statistically different at different stages of the corporate lifecycle ('Mature' vs. 'Immature' firms). The test-statistic is calculated by estimating the following regression and testing the statistical significance of $\beta_{2}$. In all three cases, the coefficient estimate for $\beta_{2}$ is positive, and statistically significant in two of three cases. High RE/TA equals 1 if firms are 'mature', that is, RE/TA is above the sample median.

$$
\begin{aligned}
\mathrm{DIV}_{i}= & \alpha+\beta_{1} \mathrm{GOV}_{i}+\beta_{2} \mathrm{GOV}_{i} \times \text { High RE} / \mathrm{TA}_{i}+\beta_{3} \text { Size }_{i}+\beta_{4} \text { Growth }_{i}+\beta_{5} \text { Profitability }_{i} \\
& +\beta_{6} \mathrm{Cash}_{i}+\beta_{7} \mathrm{TE}_{i}+\beta_{8} \text { High RE} / \mathrm{TA}_{i}+\text { Industry }_{i}+\text { Country }_{c}+\varepsilon_{i}
\end{aligned}
$$

${ }^{23}$ Brockman and Unlu (2009) and Shao et al. (2009) use country-level shareholder rights measures. Byrne and O'Connor (2012) use country and firm-level measures of shareholder rights.

${ }^{24}$ I define strong (weak) creditor rights where creditor rights are greater than (equal to and less than) 2. By defining strong creditor rights in this way, I achieve a more even distribution of firms across the two groupings i.e., high and low creditor rights. If on the other hand, I was to define strong creditor rights where creditor rights is 2 or greater, the number of firms in the weak creditor rights grouping falls to just 13 firms (from 52).

${ }^{25}$ I prefer to estimate equation (1) by stage of creditor rights (and firm maturity) as Shao et al. (2009), Byrne and O'Connor (2012) also do, and refrain from using interaction terms (e.g., corporate governance $\times$ creditor rights) because at low levels of creditor rights, the debt and equity inclusive substitution model prevails (i.e., there is a negative relationship between shareholder rights and dividend payout), but at higher levels of creditor rights, the debt and equity inclusive outcome model prevails (i.e., there is a positive relationship between shareholder rights and dividend payout). Estimating equation (1) by sub-sample is better suited to capturing these distinct effects.

${ }^{26}$ The significance tests ( $t$-statistic) outlined in Table 4 , test whether the coefficient estimates on the corporate governance variable is statistically different in different creditor rights regimes (Above and below-median creditor rights). The test-statistic is calculated by estimating the following regression and testing the statistical significance of $\beta_{2}$. In all three cases, the coefficient estimate for $\beta_{2}$ is positive, and statistically significant in two of three cases. High Creditor equals 1 if creditor rights are greater than the sample median, and zero otherwise.

$$
\begin{aligned}
\mathrm{DIV}_{i}= & \alpha+\beta_{1} \mathrm{GOV}_{i}+\beta_{2} \mathrm{GOV}_{i} \times \text { High Creditor }_{i}+\beta_{3} \text { Size }_{i}+\beta_{4} \text { Growth }_{i}+\beta_{5} \text { Profitability }_{i} \\
& +\beta_{6} \mathrm{Cash}_{i}+\beta_{7} \mathrm{TE}_{i}+\beta_{8} \mathrm{RE} \mathrm{TA}_{i}+\beta_{9} \text { High Creditor }_{i}+\text { Industry }_{i}+\varepsilon_{i}
\end{aligned}
$$

${ }^{27}$ In Appendix 2, I present coefficient estimates estimated by weighted least squares by level of firm maturity (RE/TA) and strength of creditor rights. These coefficient estimates serve to confirm the findings presented in Table 4.

${ }^{28}$ I would like to sincerely thank Sohnke Bartram for providing me with his dividend tax advantage data.

${ }^{29}$ The conclusions remain the same when I use either dividends to cashflow (\%) or dividends to sales $(\%)$.

${ }^{30}$ Interestingly, the results presented in Table 5 suggest that growth is negatively related to dividend payout, but only for 'mature' firms. Presumably, since many 'immature' firms do not pay a dividend, differences in growth rates across firms do not lead to differences in dividend payout across these same firms. Growth negatively affects the dividend payouts of 'mature' firms, likely because these firms pay a dividend, and 'mature' firms exhibit much greater variation in dividend payouts than do 'immature' firms.

${ }^{31}$ Social awareness has a $10 \%$ weighting, while the other six (management discipline, transparency, independence, accountability, responsibility, fairness) have a $15 \%$ weighting in the composite corporate governance measure. 
${ }^{32}$ Note than in Table 7, I use the ratio of cash to total assets to proxy for the corporate life-cycle for the original sample of 220 firms.

\section{Appendix 1: Variable description}

\begin{tabular}{|c|c|c|}
\hline Variable & $\begin{array}{l}\text { Description (With Worldscope identification number } \\
\text { where relevant) }\end{array}$ & Source \\
\hline $\begin{array}{l}\text { Dividends to } \\
\text { earnings }(\%)\end{array}$ & $\begin{array}{l}\text { (Dividends per share (WS05101)/earnings per share } \\
(\text { WS05201) } \times 100\end{array}$ & Worldscope \\
\hline $\begin{array}{l}\text { Dividends to } \\
\text { cashflow }(\%)\end{array}$ & $\begin{array}{l}\text { (Dividends per share (WS05101)/cashflow per share } \\
(\text { WS05510) }) \times 100\end{array}$ & Worldscope \\
\hline Dividends to sales $(\%)$ & $\begin{array}{l}(\text { Dividends per share }(\mathrm{WS} 05101) / \text { sales per share } \\
(\text { WS05508) }) \times 100\end{array}$ & Worldscope \\
\hline Size & Log of book assets in US\$ (WS02999) & Worldscope \\
\hline Growth & Logarithmic one-year asset growth (WS02999) & Worldscope \\
\hline Profitability & $\begin{array}{l}\text { Earnings before interest and taxation (EBIT) } \\
\text { (WS18191) to book assets (WS02999) }\end{array}$ & Worldscope \\
\hline Cash & Cash (WS02003) scaled by book assets (WS02999) & Worldscope \\
\hline Total equity & $\begin{array}{l}\text { Total shareholders' equity (WS03995) scaled by } \\
\text { book assets (WS02999) }\end{array}$ & Worldscope \\
\hline $\begin{array}{l}\text { Retained equity } \\
\text { to total assets }\end{array}$ & $\begin{array}{l}\text { Retained equity (WS03495) to total assets } \\
\text { (WS02999) }\end{array}$ & Worldscope \\
\hline $\begin{array}{l}\text { Retained equity } \\
\text { to total equity }\end{array}$ & $\begin{array}{l}\text { Retained equity (WS 03495) to total equity } \\
\text { (WS03995) }\end{array}$ & Worldscope \\
\hline Corporate governance & $\begin{array}{l}\text { Equally-weighted composite measure of six distinct } \\
\text { governance categories, namely management } \\
\text { discipline, transparency, independence, } \\
\text { accountability, responsibility, and fairness }\end{array}$ & CLSA (2001) \\
\hline Shareholder rights & $\begin{array}{l}\text { Both Spamann (2010) and Djankov, La Porta, } \\
\text { Lopez-de-Silanes and Shleifer (DLLS) } \\
\text { (Djankov et al., 2008) present a revised version of } \\
\text { the original version of the anti-director rights index } \\
\text { of La Porta et al. (1998). The index of DLLS (2008) } \\
\text { ranges from } 1 \text { (weak shareholder rights) to } 5 \text { (strong } \\
\text { shareholder rights). The Spamann (2010) index } \\
\text { ranges from } 2 \text { to } 5 \text { (using } 1997 \text { values) and } 2 \text { to } 6 \\
\text { (using } 2005 \text { values) }\end{array}$ & $\begin{array}{l}\text { Spamann }(2010) \\
\text { and Djankov et al. } \\
(2008)\end{array}$ \\
\hline \multirow[t]{2}{*}{ Creditor rights } & $\begin{array}{l}\text { An index aggregating creditor rights, following } \\
\text { La Porta et al. (1998) }\end{array}$ & $\begin{array}{l}\text { Djankov et al. } \\
(2007)\end{array}$ \\
\hline & $\begin{array}{l}\text { The index ranges from } 0 \text { (weak creditor rights) to } 4 \\
\text { (strong creditor rights) and is constructed as at } \\
\text { January for every year from } 1978 \text { to } 2003 \text {. I use } \\
\text { creditor rights for the year } 2001\end{array}$ & \\
\hline $\begin{array}{l}\text { Dividend tax } \\
\text { advantage }\end{array}$ & $\begin{array}{l}\text { Measured as the after-tax value of one dollar paid } \\
\text { out in dividends divided by the after-tax value of one } \\
\text { dollar paid out in capital gains }\end{array}$ & $\begin{array}{l}\text { Bartram et al. } \\
\text { (2012), Fidrmuc } \\
\text { and Jacob (2010) }\end{array}$ \\
\hline
\end{tabular}


Appendix 2: Regression estimates by level of RE/TA and creditor rights

\begin{tabular}{|c|c|c|c|c|c|c|}
\hline & \multicolumn{6}{|c|}{ Dividend payout measure } \\
\hline & \multicolumn{2}{|c|}{$\begin{array}{c}\text { Dividends to earnings } \\
(\%)\end{array}$} & \multicolumn{2}{|c|}{$\begin{array}{c}\text { Dividends to cashflow } \\
(\%)\end{array}$} & \multicolumn{2}{|c|}{$\begin{array}{c}\text { Dividends to sales } \\
(\%)\end{array}$} \\
\hline & $\begin{array}{c}\text { Low } \\
\text { creditor }\end{array}$ & $\begin{array}{c}\text { High } \\
\text { creditor }\end{array}$ & $\begin{array}{c}\text { Low } \\
\text { creditor }\end{array}$ & $\begin{array}{c}\text { High } \\
\text { creditor }\end{array}$ & $\begin{array}{c}\text { Low } \\
\text { creditor }\end{array}$ & $\begin{array}{c}\text { High } \\
\text { creditor }\end{array}$ \\
\hline \multicolumn{7}{|c|}{ High RE/TA (Mature) } \\
\hline $\begin{array}{l}\text { Corporate } \\
\text { governance }\end{array}$ & $\begin{array}{l}0.173 \\
(0.54)\end{array}$ & $\begin{array}{l}0.380 \\
(1.44)\end{array}$ & $\begin{array}{l}0.038 \\
(0.14)\end{array}$ & $\begin{array}{c}0.495 * * \\
(2.43)\end{array}$ & $\begin{array}{l}0.146^{* * *} * \\
\quad(2.97)\end{array}$ & $\begin{array}{l}0.211 * * * \\
\quad(4.16)\end{array}$ \\
\hline Controls & Yes & Yes & Yes & Yes & Yes & Yes \\
\hline $\begin{array}{l}\text { Country } \\
\text { dummies }\end{array}$ & No & No & No & No & No & No \\
\hline $\begin{array}{l}\text { Industry } \\
\text { dummies }\end{array}$ & Yes & Yes & Yes & Yes & Yes & Yes \\
\hline \# Firms & 52 & 58 & 52 & 58 & 52 & 58 \\
\hline \multirow[t]{3}{*}{$R$-squared } & 0.257 & 0.331 & 0.365 & 0.202 & 0.518 & 0.291 \\
\hline & \multicolumn{6}{|c|}{ Tests of significance ( $t$-test) } \\
\hline & \multicolumn{2}{|c|}{0.77} & \multicolumn{2}{|c|}{$2.08 * *$} & \multicolumn{2}{|c|}{1.39} \\
\hline \multicolumn{7}{|c|}{ Low RE/TA (Immature) } \\
\hline $\begin{array}{l}\text { Corporate } \\
\text { governance }\end{array}$ & $\begin{array}{c}-0.182 \\
(0.43)\end{array}$ & $\begin{array}{l}0.999 * * * \\
(3.03)\end{array}$ & $\begin{array}{l}0.163 \\
(0.65)\end{array}$ & $\begin{array}{c}0.544 * * \\
(2.42)\end{array}$ & $\begin{array}{l}0.002 \\
(0.05)\end{array}$ & $\begin{array}{l}0.059 \\
(1.09)\end{array}$ \\
\hline Controls & Yes & Yes & Yes & Yes & Yes & Yes \\
\hline $\begin{array}{l}\text { Country } \\
\text { dummies }\end{array}$ & No & No & No & No & No & No \\
\hline $\begin{array}{l}\text { Industry } \\
\text { dummies }\end{array}$ & Yes & Yes & Yes & Yes & Yes & Yes \\
\hline \# Firms & 74 & 36 & 74 & 36 & 74 & 36 \\
\hline \multirow[t]{3}{*}{$R$-squared } & 0.209 & 0.423 & 0.350 & 0.284 & 0.422 & 0.323 \\
\hline & \multicolumn{6}{|c|}{ Tests of significance ( $t$-test) } \\
\hline & \multicolumn{2}{|c|}{$2.56^{* * *}$} & \multicolumn{2}{|c|}{$2.14 * * *$} & \multicolumn{2}{|c|}{1.45} \\
\hline
\end{tabular}

This table reports coefficient estimates from weighted least squares regressions with heteroscedastic consistent $t$-stats presented underneath in parenthesis. The weight of each observation (firm) is the inverse of the number of observations (firms) in each country. The sample period is for the year 2001. Separate regressions are estimated for firms with high (above-median) and low (below-median) retained equity to total assets (RE/TA), domiciled in countries with high (above-median i.e., creditor rights measure greater than and equal to 2) and low (below-median i.e., creditor rights measure less than 2) creditor rights. The dependent variable is dividends to earnings (\%), dividends to cashflow (\%), and dividends to sales (\%), as indicated. A full set of controls are included, but not reported. All firm-level data is sourced from Worldscope. Corporate governance measures are from CLSA (2001). \# Firms is the number of firms, and *,**, and *** denotes significance at the $10 \%, 5 \%$, and $1 \%$ level, respectively. The significance tests ( $t$-statistic) test whether the coefficient estimates on the corporate governance variable is statistically different in different creditor rights regimes. The test-statistic is calculated by estimating the following regression and testing the statistical significance of $\beta_{2}$. High Creditor equals 1 if creditor rights are equal to and greater than 2 , and zero otherwise.

$$
\begin{aligned}
\mathrm{DIV}_{i}= & \alpha+\beta_{1} \mathrm{GOV}_{i}+\beta_{2} \mathrm{GOV}_{i} \times \text { High Creditor }_{i}+\beta_{3} \text { Size }_{i}+\beta_{4} \text { Growth }_{i}+\beta_{5} \text { Profitability }_{i} \\
& +\beta_{6} \mathrm{Cash}_{i}+\beta_{7} \mathrm{TE}_{i}+\beta_{8} \mathrm{RE}_{i}+\beta_{9} \text { High Creditor }_{i}+\text { Industry }_{i}+\varepsilon_{i}
\end{aligned}
$$

